\title{
OWNERSHIP STRUCTURE IN FOREIGN DIRECT INVESTMENT PROJECTS
}

\author{
Elizabeth Asiedu and Hadi Salehi Esfahani*
}

Abstract-This paper theoretically and empirically examines ownership structure in foreign direct investment (FDI) projects. We show that in choosing an ownership structure, foreign investors, local entrepreneurs, and government consider the specific, costly-to-market assets that the participants and the country bring to the project. In equilibrium, the foreign equity share rises with the importance of foreign investor assets and declines with the contribution of local assets towards the amount of surplus generated in the project. Government policies and the institutional structure of the country also affect ownership structure.

\section{Introduction}

$\mathrm{T}$ HIS paper examines the sources of variation in the equity structure of foreign direct investment (FDI) projects. We develop a theoretical framework and apply it empirically to assess the relationship of the foreign equity share in an FDI project with the characteristics of the industry, the host country, and the investing transnational enterprise (TNE). Our goal is to discern the extent to which ownership structures are determined by equity restrictions and other policy factors as opposed to the economic and institutional conditions prevailing in the host country.

Understanding the ownership structure of FDI projects is important because the structure affects the incentives of the investors to apply their resources to the project. Equity shares influence the cost of capital, the level of investment, the degree of technology transfer, and the distribution of gains from FDI. Furthermore, a TNE's equity position determines the extent to which the TNE can control its subsidiary and protect the integrity of the TNE's assets. ${ }^{1}$ Governments are also interested in equity shares and sometimes impose ownership restrictions to tilt the distribution of project rents in favor of their nationals, although this may discourage FDI. This policy issue has gained prominence in the past two decades because few developing countries have attracted sizable FDI despite the worldwide surge in FDI flows. ${ }^{2}$ Many analysts have held restrictive government policies-in particular, ownership restrictions-responsible for the failure to attract FDI and have offered liberalization as the key solution. However, many of the countries that liberalized did not experience an increase in FDI, suggesting

Received for publication October 8, 1998. Revision accepted for publication November 29, 2000.

* University of Kansas and University of Illinois at Urbana-Champaign, respectively.

We are indebted to Janet Fitch, Donald Lien, Tom Pugel, Joe Sicilian, Anne Villamil, Thomas Weiss, and two anonymous referees for helpful comments on earlier drafts of this paper. We are grateful for the financial support of the Center for International Business Education and Research at the University of Illinois at Urbana-Champaign.

${ }^{1}$ Following Grossman and Hart (1986), we consider ownership and control as synonymous.

${ }^{2}$ FDI flows to developing countries increased from \$24 billion in 1990 to $\$ 208$ billion in 1999. However, these investments are concentrated in a few countries. For example, in 1999 about 80\% of FDI to developing countries went to only ten countries (World Bank, 2000). that the restrictions may not have been very binding (Contractor, 1991; UNCTD, 1995). Our study offers important insights in this regard.

The model developed here is based on the idea that FDI entails the use of inputs that are costly to transact on the market. ${ }^{3}$ Indeed, the main rationale for foreign production is that TNEs possess intangible assets that are costly to transact at arm's length. ${ }^{4}$ Moreover, FDI projects need local knowledge and connections possessed by local entrepreneurs, which are also assets subject to high transaction costs. Although either the local entrepreneur or the TNE can obtain the inputs of the other side at some cost through market transactions and maintain full ownership, joint ownership offers an alternative that reduces reliance on markets. However, joint ownership entails other costs, such as weakened incentives to supply inputs (Hennart, 1988). Incentive problems can be solved if side payments are costless and partners can be rewarded according to their marginal contributions while the surplus is distributed according to the relative bargaining power of the two partners (Svejnar \& Smith, 1984). However, when side payments are restricted, the preferences of joint venture partners over sharing rules diverge. Governments may also intervene to retain more rents in the country. The outcome is a game between the TNE, local entrepreneurs, and the government with divergent preferences over foreign share and efficiency.

The presence of rents and side-payment restrictions in FDI projects is crucial to our results. The existence of rents in matches that form between countries and TNEs is plausible because countries differ in their institutions, resources, and demand characteristics and tend to offer different returns on the specific assets owned by TNEs. Constraints on side payments are partly due to the government's effort to control transfer pricing for tax purposes and to keep the rents of FDI projects in the host country. Also, TNEs have an informational advantage over local partners and the government that allows them to capture some minimum amount of rent. ${ }^{5}$

This study builds on the two main approaches-bargaining and transactions cost-used in the literature to analyze equity structures. The bargaining approach, pioneered by Vernon (1971) and extended in a more rigorous form by Svejnar and Smith (1984), models a TNE's equity position as the outcome of a bargaining game between a TNE and its local partners. The bargaining power of the TNE (and,

\footnotetext{
${ }^{3}$ This aspect of our model originates from the sharecropping model of Eswaran and Kotwal (1985).

${ }^{4}$ See Caves (1982) and Markusen (1995) for reviews of literature on the role of intangible assets in TNE formation.

${ }^{5}$ The role of private information and match-specific capital in FDI projects is analyzed by Choi and Esfahani (1998).
} 
hence, its equity share) is typically assumed to increase with the benefits that the TNE brings to the host country (such as assets and exports) and to decrease with the attractiveness of the host country's internal market (such as a large and growing market, cost-effective labor, and good infrastructure). However, these relationships are not derived from first principles. Moreover, for many of the factors considered, it is not clear from the theory why a change in bargaining power translates into a change in equity share rather than simply a change in the returns to the supplied inputs. ${ }^{6}$

The transactions-cost theory of equity structure posits that the choice between whole and joint ownership depends on the benefits of avoiding costly arm's-length transactions relative to the costs of sharing ownership (such as difficulties in decision making, reduced incentives, and free riding by partners). ${ }^{7}$ Here, the focus is on the role of intangible, often knowledge-based assets that are costly to exchange on the market because of potential opportunistic behavior. However, the modeling has often been heuristic and has lacked sufficient structure to produce predictions about equity shares beyond the choice of whole versus joint ownership. In particular, the relationship between equity shares and the relative contribution of each partners' assets to production is not considered. In addition, the existing transaction-cost models rarely specify the conditions under which recruiting local entrepreneurs as partners is superior to hiring them as employees.

This paper advances the transaction-cost approach by developing and testing a structural model that relates the business conditions of a project to its equity composition. Our model incorporates the factors highlighted by the bargaining framework to the extent that these factors reflect the relative capabilities of different partners to shape the project's output. The model also specifies the government's motivation in restricting foreign equity share. This is an important advantage over most of the existing literature, which treats equity restrictions as ad hoc activity by the government. ${ }^{8}$ Another advantage of our model is that it provides an active role for local entrepreneurs and specifies the importance of the host country's institutions in equity ownership decisions. ${ }^{9}$ These factors, which turn out to be empirically important, have received little attention in the literature on equity structure. Finally, the model ties together the roles played by a host of factors in equity

\footnotetext{
${ }^{6}$ This approach can also be criticized for inconsistencies with some empirical regularities. For example, according to the bargaining theory, joint ventures and low TNE equity shares should be more common among FDI projects in industrialized countries than in developing countries, whereas the data indicates otherwise.

${ }^{7}$ See Gomes-Casseres (1990), Hennart (1991), Erramilli (1996), Pan (1996), and Henisz (1997). See Hennart (1988, 1990) for a detailed discussion of transactions cost theory as a rationale behind a firm's equity structure.

${ }^{8}$ Exceptions include Falvey and Fried (1986), Stoughton and Talmor (1994), and Dasgupta and Sengupta (1995).

${ }^{9}$ Stopford and Wells (1972) and Beamish (1994) use survey data to suggest that local partners and the host country's institutions play important roles in business operations, especially in developing countries.
}

ownership decisions. Many subgroups of the variables considered here have been included in previous studies, but the role of each has been explained separately, sometimes with conflicting implications. We are able to explain a variety of observed relationships from a unified perspective.

For our empirical work, we use a data set based on a large sample of subsidiaries of U.S. TNEs. Compared with other empirical studies, our data set is larger and has more recent information. ${ }^{10}$ Moreover, unlike other studies that use a dichotomous ownership indicator (such as minority versus majority), we use data on the actual shares in joint ventures. We also create innovative measures of nonmarketable assets and successfully relate them to the theory of transnational enterprises. The results show that the equilibrium foreign share rises with the importance of TNE assets for production and declines with the significance of local assets. On the other hand, any host country characteristic that increases the productivity of local assets in the project tends to lower the foreign share. Equity restrictions turn out to be consequential, although only as one of institutional and policy factors that affect the foreign share.

The paper proceeds as follows. Section II describes the theoretical model. Section III specifies the econometric model and the variables. Section IV presents the empirical results, and section $\mathrm{V}$ concludes.

\section{The Model}

Consider a TNE that has identified a profitable FDI project in a host country. ${ }^{11}$ Local assets can generate rents if combined with specific noncontractible intangible assets of the TNE such as technological and managerial know-how, international marketing connections, and so forth. Two types of local assets are assumed to be unavailable through competitive markets. The first type, which we shall refer to as infrastructure, is composed of local public goods, access to markets, rule of law, and the quality of institutions more generally. ${ }^{12}$ These assets are too costly to transact through the market and contribute to the productivity of the project without the subsidiary having to pay for them directly.

The second type of local asset, which we shall refer to as local inputs, consists of factors that facilitate production and marketing, such as local technologies, knowledge of local markets and labor characteristics, and personal connections

\footnotetext{
${ }^{10}$ Past empirical studies have generally been based on data from the 1975 Harvard Multinational Database (Anderson \& Gatignon, 1988; Gomes-Caserres, 1989, 1990). An exception is Henisz (1997), who uses a more recent and large data set similar to ours.

${ }^{11}$ A TNE's decision to invest abroad can be modeled as a two-step process. First, the TNE decides whether or not to establish a subsidiary in a particular country. If it chooses to invest, it then decides whether to establish a wholly owned subsidiary or a joint venture with a local partner. We focus only on the latter decision.

${ }^{12}$ Besides adding realism, the presence of such assets in the model serves two purposes. First, the assets act as a fixed factor and give rise to diminishing returns, which ensures that the equilibrium size of the project is finite. Second, their presence provides a foundation for the existence of match-specific capital whose rents motivate government intervention.
} 
with policymakers that can help reduce bureaucratic delays. These assets can be either supplied by local entrepreneurs or produced by the TNE. However, the cost to the TNE would be higher if it chooses to produce them itself or obtain them through an arm's-length transaction. The additional cost of self-production may be viewed as the extra resources (such as extra time and energy) that the TNE's managers have to expend to acquire knowledge of the local economy and customs or as extra payments that they have to make to elicit bureaucratic cooperation. ${ }^{13}$ When a local entrepreneur joins the subsidiary as a partner, he partially internalizes the returns to his inputs.

Let $t$ denote the summary measure of all the resources needed to apply the TNE's assets to the project. Similarly, let $k$ be a measure for the provision of local inputs. Assume that the process of combining infrastructure services, $A$, with the foreign and local inputs is Cobb-Douglas: ${ }^{14}$

$$
Q=\left(A^{\eta} t^{\lambda} k^{v}\right)^{1 /(\eta+\lambda+v)},
$$

where $Q$ is the output of the project net of the costs of all competitively supplied inputs. $\eta, \lambda$, and $\nu$ are parameters that represent, respectively, the importance of infrastructure, TNE assets, and local inputs in the project's operation. These parameters are fixed for a given project but vary across projects. The more extensive and effective the TNE's assets, the higher would be the value of $\lambda$. Similarly, $v$ and $\eta$ are higher when local inputs and infrastructure play more crucial roles in production. ${ }^{15}$

We normalize the price of the output to one and let $p_{t}$ and $p_{k}$ denote the unit costs of $t$ and $k$ for the TNE and the local entrepreneur, respectively. If the TNE chooses to obtain the local inputs directly, it must pay the price, $\rho p_{k}$, where $\rho>$ 1 indicates the comparative advantage of the local entrepreneur vis-à-vis the TNE in providing the inputs. Forming a joint venture absolves the TNE of the excess costs and provides partial incentives for the local partner, although it weakens the TNE's incentive to apply its own assets. For simplicity, we assume that there are many local entrepreneurs who can serve as local partners. This allows the TNE

\footnotetext{
${ }^{13}$ In the case of arm's-length transaction, the premium may be interpreted as the cost of creating incentives for local suppliers. Assuming transaction costs for the project's inputs essential for explaining the existence of FDI, joint ventures, and government intervention, otherwise one party would compensate the others and take full control.

14 The Cobb-Douglas assumption is for ease of parameterization and presentation. The results are more general.

${ }^{15}$ This interpretation of the exponents follows from the view that the project requires a wide range of inputs, and that a supplier that offers services for a larger set of those inputs is in a position to contribute more to the project. This idea can be formalized by specifying the production function as $\log Q=\int_{0}^{1} s \log x(s) d s$, where $s \in[0,1]$ is an index for a continuum of differentiated inputs required for the production of the output and $x(s)$ is the quantity of input of variety $s$. The range of input varieties supplied by the TNE would then be the equivalent of $\lambda /(\eta+\lambda+$ $v)$, a measure of the TNE's contribution to production. The roles of infrastructure and local inputs can be similarly defined. The functional form in equation (1) provides a shortcut for the analysis with this specification.
}

to extract all project rents if there is no government intervention. ${ }^{16}$

The project is required to pay tax at a fixed rate, $\tau$, on the net output. We assume that this is the only direct way that the government can extract rents from the project. This assumption captures the constraint on direct taxation of the TNE due to transfer-pricing possibilities, which the FDI literature predominantly attributes to the presence of imperfect information on the part of the government (Stoughton \& Talmor, 1994; Dasgupta \& Sengupta, 1995). ${ }^{17}$

\section{A. TNE's Preferred Equity Structure}

Under whole ownership, the TNE obtains local inputs at cost $\rho p_{k}$, and pays a fraction $\tau$ of the net output to the host government. The TNE's problem in this case is

$$
\pi_{t}^{w}=\max _{t, k}(1-\tau) Q-p_{t} t-\rho p_{k} k
$$

The solution yields

$$
\pi_{t}^{w}=A^{*} \frac{(1-\tau) \eta}{\eta+\lambda+v} \rho^{-v / \eta}
$$

where

$$
A^{*}=A\left(\frac{1-\tau}{\eta+\lambda+v}\right)^{\lambda+v / \eta}\left(\frac{\lambda}{p_{t}}\right)^{\lambda / \eta}\left(\frac{v}{p_{k}}\right)^{v / \eta} .
$$

The government's revenue is given by $\pi_{g}^{w}=\pi_{t}^{w}(\eta+\lambda+$ v) $\tau /[\eta(1-\tau)]$.

In a joint venture, the TNE offers a contract to a local entrepreneur to share the after-tax net output of the project, $(1-\tau) Q$. The contract sets an equity share, $\beta \in(0,1)$, for the TNE according to which $(1-\tau) Q$ is distributed. In addition, the contract requires a side payment, $\alpha$, from the local partner to the TNE after production. At the time of production, the two sides decide on their asset services, $t$ and $k$, which they set individually. The net return to the TNE and the local partner are, respectively,

$$
R_{t}=\alpha+\beta(1-\tau) Q-p_{t} t
$$

and

$$
R_{l}=-\alpha+(1-\beta)(1-\tau) Q-p_{k} k
$$

\footnotetext{
${ }^{16}$ Assigning some bargaining power to the local partner does not change the results, except for weakening the government's incentive to intervene.

${ }^{17}$ If the government can choose the profit tax freely, then it would not need to distort the equity share. However, as Dasgupta and Sengupta (1995) show, TNE private information imposes a binding constraint on taxation and makes it optimal for the government to restrict the TNE's share. To keep the paper short, we do not model this feature. We also abstract from differential taxation of the TNE and its local partner because the objective of the government-specified in equation (12) includes the rents of the local partner as well as tax revenues. In this setting, differential taxation is in effect a transfer between the local partner and the government that has little impact on the results.
} 
A joint venture is feasible only if both sides find it worthwhile. For the TNE, the alternative is whole ownership, and for the local entrepreneur the reservation payoff is zero. ${ }^{18}$ Therefore, a joint venture dominates whole ownership if $R_{t} \geq \pi_{t}^{w}$ and $R_{l} \geq 0$.

As noted in the introduction, we assume that there are restrictions on transfers between the TNE and the local entrepreneur. ${ }^{19}$ For simplicity, we assume that $\alpha$ is a fixed proportion, $\phi$, of the local partner's pre-transfer share in the output. ${ }^{20}$ That is,

$$
\alpha=\phi(1-\beta)(1-\tau) Q .
$$

Given the value of $\alpha$, the payoffs in equations (4) and (5) become

$$
\begin{aligned}
& R_{t}=\gamma(1-\tau) Q-p_{t} t, \\
& R_{l}=(1-\gamma)(1-\tau) Q-p_{k} k,
\end{aligned}
$$

where $\gamma=1-(1-\phi)(1-\beta)$ is the effective share of the TNE. The optimal choices of $t$ and $k$ from the perspectives of the TNE and the local entrepreneur, respectively, would be

$$
t^{*}=\frac{\lambda}{\eta+\lambda+v} \gamma(1-\tau) Q^{*} / p_{t}
$$

and

$$
k^{*}=\frac{v}{\eta+\lambda+v}(1-\gamma)(1-\tau) Q^{*} / p_{k},
$$

where $Q^{*}$ is determined by

$$
Q^{*}=A^{*}(\gamma)^{\lambda / \eta}(1-\gamma)^{v / \eta} .
$$

Knowing the above outcome, the TNE would choose $\beta$ (and, therefore, $\gamma$ ) to maximize:

$$
R_{t}^{*}=\left(\frac{\eta+v}{\eta+\lambda+v}\right) \gamma(1-\tau) Q^{*}
$$

\footnotetext{
${ }^{18}$ Assuming a positive reservation payoff for the local entrepreneur does not change the main results.

${ }^{19}$ In the absence of a transfer constraint, sharing has no consequence for efficiency. To see this, note that, when $\alpha$ is unconstrained, competition among the local entrepreneurs allows the TNE to set $\alpha=(1-\beta)(1-$ $\tau) Q-k+\epsilon[(1-\tau) Q-k-t]$, where $\epsilon>0$ is a small number. This induces the partners to choose $t$ and $k$ so as to maximize the total profit of the project. The same result obtains if the local partner has bargaining power and the two sides engage in a Nash bargaining game without transfer restrictions (Svejnar \& Smith, 1984).

${ }^{20} \alpha$ may be specified in many other forms or derived from basic principals. But, such variations do not change the results substantially as long as the marginal payoff of each partner depends on equity shares. Our assumption satisfies this requirement in an innocuous way, while avoiding unnecessary complications.
}

The solution to this problem is simply

$$
\gamma_{t}=\frac{\eta+\lambda}{\eta+\lambda+v} \Rightarrow \beta_{t}=1-\frac{v /(1-\phi)}{\eta+\lambda+v}
$$

The TNE's payoff from a joint venture, $\pi_{t}^{j v}$, would be equal to $R_{t}^{*}$ with $\gamma=\gamma_{t}$. The TNE prefers an effective share that covers its own contribution to the net output-that is, $\lambda /(\eta+\lambda+\nu)$-as well as that of infrastructure - that is, $\eta /(\eta+\lambda+\nu)$. If the TNE could directly extract the project's rents, it would seek the efficient share, $\beta=\lambda /(\eta+$ $\lambda+v)$. Because of restrictions on side payments, the TNE is willing to sacrifice efficiency in order to capture more of the project's rents. Note that, as $\eta$ increases, this tradeoff tilts more in favor of a larger share for the TNE. Equation (10) indicates that $\gamma_{t}$ and $\beta_{t}$ are increasing in $\lambda$ and decreasing in $\nu$. Thus, as the importance of a production factor rises, it is optimal for the TNE to raise the factor owner's share, maintaining balance in the incentive and redistribution effects of $\beta$. The tax rate, $\tau$, does not play any role in the optimal choice of $\beta_{t}$ because, from the TNE's perspective, $\tau$ is simply a scaling factor for the net output.

The TNE would prefer whole ownership to a joint venture with $\beta=\beta_{t}$ if $\pi_{t}^{w} \geq \pi_{t}^{j v}$, that is, if

$$
1 \geq \frac{\eta+v}{\eta}\left(\gamma_{t}\right)^{(\eta+\lambda) / \eta}\left[\left(1-\gamma_{t}\right) \rho\right]^{\nu / \eta}
$$

Let $\beta_{t}^{*}$ denote the TNE's preferred equity position. Then, taking into account the possibility of random effects in the TNE's decision making, equations (10) and (11) imply that the probability that $\beta_{t}^{*}=1$ rises with $\lambda$ and declines with $\rho$. In appendix $A$, we show that $\operatorname{Prob}\left\{\beta_{t}^{*}=1\right\}$ declines with $v$ when the two sides of equation (11) are close to each other and variations in the system are most likely to affect the TNE's choice. The impact of $\eta$ on the choice between whole and partial ownership depends on the size of $\lambda$ relative to $\eta$ and $\nu$ : it is positive when $\lambda$ is relatively large and negative when $\lambda$ is relatively small.

\section{B. Government's Preferred Equity Structure}

The government's objective is to increase the amount of project surplus that stays in the country. ${ }^{21}$ Thus, from the government's perspective, the optimal effective share of the TNE in joint venture, $\gamma_{g}$, should maximize:

\footnotetext{
${ }^{21}$ The government may weigh the profits of entrepreneurs differently from its own revenues. Adding such a weight does not have any qualitative impact on the results. Also, note that the host government's objective in retaining rents may seem at odds with subsidies that are often offered to TNEs in the form of tax holidays and infrastructure provision. However, as the literature on time inconsistency problems in FDI policies has shown, these subsidies mainly pay for the sunk investments whose quasi-rents are subject to subsequent capture by the host government. (See, among others, Doyle and van Wijnbergen (1994) and, most recently, Schnitzer (1999).)
} 
Table 1.-Impact of the Model's Parameters on Equity Structure Preferences

\begin{tabular}{llllll}
\hline \hline \multicolumn{1}{c}{ Parameters } & \multicolumn{1}{c}{$\eta$} & $\lambda$ & $\nu$ & $\tau$ & $\rho$ \\
\hline$\beta_{t}$ & + & + & - & 0 & 0 \\
$\beta_{g}$ & - & + & - & + & 0 \\
$\operatorname{Prob}\left\{\beta_{t}^{*}=1\right\}$ & + if $\lambda$ is large & + & - & 0 & - \\
$\operatorname{Prob}\left\{\beta_{g}^{*}=1\right\}$ & - if $\lambda$ is small & & & & \\
\hline
\end{tabular}

$$
\begin{aligned}
R_{l}+\tau Q^{*} & =(1-\gamma)(1-\tau) Q^{*}-p_{k} k^{*}+\tau Q^{*} \\
& =\left[\tau+\left(\frac{\eta+\lambda}{\eta+\lambda+\nu}\right)(1-\gamma)(1-\tau)\right] Q^{*} .
\end{aligned}
$$

$\gamma_{g}$ (and its associated contractual share, $\beta_{g}$ ) is determined by

$$
\begin{gathered}
(1-\tau)(\eta+\lambda)\left(1-\gamma_{g}\right)\left[\gamma_{g}-\frac{\lambda}{\eta+\lambda+v}\right] \\
+\tau(\lambda+\nu)\left[\gamma_{g}-\frac{\lambda}{\lambda+\nu}\right]=0 .
\end{gathered}
$$

In Appendix $A$, we show that $\beta_{g}<\beta_{t}$ and that $\gamma_{g}$ and $\beta_{g}$ are increasing in $\tau$. The government cannot extract all the project's rents by direct taxation and sees a lower share for the TNE as a mechanism to redistribute rents towards the local partner. If $\tau$ could be raised, the government would receive a larger share of the rents directly and would find the distributional role of $\beta$ less significant. We also show that $\gamma_{g}$ and $\beta_{g}$ are increasing in $\lambda$ and decreasing in $\eta$ and $\nu$.

The government would prefer full ownership if $\pi_{g}^{w} \geq$ $\pi_{g}^{j v}$, where $\pi_{g}^{j v}$ is the maximized value of the government's objective function under joint ownership. This is the case if

$$
\begin{aligned}
1 \geq & {\left[1+\left(\frac{1-\tau}{\tau}\right)\left(\frac{\eta+\lambda}{\eta+\lambda+\nu}\right)\left(1-\gamma_{g}\right)\right] } \\
& \times\left(\gamma_{g}\right)^{\lambda / \eta}\left[\left(1-\gamma_{g}\right) \rho\right]^{\nu / \eta} .
\end{aligned}
$$

Let $\beta_{g}^{*}$ denote the government's preferred $\beta$. Taking into account random factors, it follows from equation (14) that $\operatorname{Prob}\left\{\beta_{g}^{*}=1\right\}$ rises with $\lambda$ and $\tau$ and declines with $\eta$. The effect of $\nu$ is unclear. (See appendix A.)

\section{Discussion}

Our results so far are summarized in table 1 . Both $\beta_{g}$ and $\beta_{t}$ are increasing in $\lambda$ and decreasing in $v$; the government and the TNE agree over the incentive effects of equity shares. In contrast, an increase in the contribution of infrastructure, $\eta$, causes divergence in the preference for equity shares; as the project's rents rise, the TNE desires a larger share, whereas the government finds a lower $\beta$ more palatable. Note that the comparative advantage of local entrepreneurs in providing the local input, $\rho$, has no impact on preferences over $\beta$ under a joint venture. The reason is that, in the presence of a local partner, the TNE's direct costs of procuring local inputs are irrelevant.

Table 1 shows that, for both the TNE and the government, the preference for whole ownership is driven by factors that are different from those influencing the preferred $\beta$ in a joint venture. Although $\lambda$ and $\tau$ influence the probabilities of whole ownership in the same way that they affect $\beta_{g}$ and $\beta_{t}$, this is not the case for $\eta, \nu$, and $\rho$. Whereas the effects of $\eta$ and $\nu$ on both $\beta_{g}$ and $\beta_{t}$ can be clearly signed, there is ambiguity about the effect of $\eta$ on $\operatorname{Prob}\left\{\beta_{t}^{*}=1\right\}$ and of $\nu$ on $\operatorname{Prob}\left\{\beta_{g}^{*}=1\right\}$. More significantly, $\rho$, which is inconsequential in determining $\beta$ under a joint venture, affects the choice between joint versus whole ownership, with both the TNE and the government finding a joint venture more attractive as $\rho$ rises.

Note that the relative costs of inputs, $p_{t}$ and $p_{k}$, play no role in the ownership decision. This is due to the unit elasticity of substitution in the Cobb-Douglas function. If the production function has a larger substitution elasticity, a factor's contribution to output rises as its price falls. Our present specification can simulate this if we interpret a decline in the price of $t$ or $k$ as an increase in $\lambda$ or $\nu$, respectively. A lower substitution of elasticity implies the opposite. Because we don't know the values of substitution elasticities, we use 1, which is the typical finding for aggregate production functions, as an average.

\section{Equilibrium Equity Structure}

Our model highlights key factors that motivate the government to restrict the contractual foreign share, $\beta$. The government may refrain from restricting foreign ownership for two reasons. First, governments often have incomplete information about individual projects and follow a liberal policy in order to avoid inefficiencies of applying the same restrictions to a range of projects. Second, the government may prefer whole foreign ownership to a joint venture even though its preferred share under a joint venture is lower than that of the TNE. We model the role of incomplete information about individual projects by assuming that the government's policy toward foreign share takes the form of a variable, $\bar{\beta}$, that is related to $\beta_{g}$ by $\bar{\beta}=\beta_{g}+\mu+\theta$. Here, $\theta$ is a random variable with a zero mean, and $\mu \leq \eta /(\eta+$ $\lambda+v)$ is a parameter that reflects the extent to which the government prefers to avoid errors resulting from overly restrictive policies. The government would impose a limit on the foreign equity share if $\bar{\beta}<1 .{ }^{22}$ In that case, the expected value of the equilibrium equity share under a joint venture, $\beta^{*}$, is given by

$$
\begin{aligned}
E\left(\beta^{*}\right)= & E\left(\beta_{t}^{*}\right)-\operatorname{Prob}\left\{\beta_{t}^{*}<\beta_{g}+\mu+\theta\right\} \\
& \times\left[E\left(\beta_{t}^{*}\right)-\beta_{g}-\mu\right] .
\end{aligned}
$$

\footnotetext{
${ }^{22} \bar{\beta}$ may be a ceiling formally imposed on a class of projects through laws and decrees or a limit imposed informally on individual projects in the negotiation between the government and the TNE.
} 
The government's inclination to follow more liberal policies (that is, higher $\mu$ ) tends to reduce the likelihood of binding equity restrictions. We do not observe $\mu$ directly, but it may be inferred from the percentage of TNEs reporting binding equity restrictions in each country, $\bar{F}$, for which data is available. This percentage may be interpreted as the average of $\operatorname{Prob}\left\{\beta_{t}^{*}<\beta_{g}+\mu+\theta\right\}$ over all FDI projects in each country. Therefore, the last term on the right-hand side of equation (15) can be expressed as a function of $\bar{F}$ and $E\left(\beta_{t}^{*}\right)-\beta_{g}$. Using a linearized version of this function, we obtain

$$
\begin{aligned}
E\left(\beta^{*}\right) & \approx E\left(\beta_{t}^{*}\right)-\sigma\left[E\left(\beta_{t}^{*}\right)-\beta_{g}\right]-\omega \bar{F} \\
& =(1-\sigma) E\left(\beta_{t}^{*}\right)+\sigma \beta_{g}-\omega \bar{F}
\end{aligned}
$$

where $0<\sigma<1$ and $\omega>0$ are parameters. Given the impact of the model's parameters on $E\left(\beta_{t}^{*}\right)$ and $\beta_{g}$, it is easy to see that $E\left(\beta^{*}\right)$ rises with $\lambda$ and $\tau$, and declines with $\nu$ and $\mu$, but the impact of $\eta$ is unclear. $E\left(\beta^{*}\right)$ is also inversely related to $\rho$ to the extent that, in joint ventures, the TNE may prefer whole ownership. Because typically a minority of firms actually complain about binding equity restrictions, it is likely that $\rho$ has little weight on the right-hand side of equation (16). ${ }^{23}$ This contrasts with the whole ownership decision in which $\rho$ plays an important role.

The likelihood that a wholly owned subsidiary emerges as the outcome for the project (that is, $\operatorname{Prob}\left\{\beta^{*}=1\right\}$ ) can be derived in a similar fashion. Note that

$$
\begin{aligned}
& \operatorname{Prob}\left\{\beta^{*}=1\right\}=\operatorname{Prob}\left\{\beta_{t}^{*}=1 \cap \bar{\beta} \geq 1\right\} \\
& =\operatorname{Prob}\left\{\beta_{t}^{*}=1\right\}-\operatorname{Prob}\left\{\beta_{t}^{*}=1 \cap \bar{\beta}<1\right\} .
\end{aligned}
$$

The last term on the right-hand side of equation (17) is the probability that the TNE faces a binding equity restriction when it prefers a wholly owned subsidiary. As in the case of a joint venture, the probability of full TNE ownership can be expressed as a function of the parameter $\mu$ (again proxied by the economy-wide probability of binding equity restrictions, $\bar{F}$ ) and the factors that affect the TNE's and the government's preferences for whole ownership. Based on the results presented in table 1 , it can be seen that $\operatorname{Prob}\left\{\beta^{*}=1\right\}$ decreases with $\rho$ and increases with $\lambda, \tau$, and $\mu$. The effects of $\eta$ and $v$ are unclear. However, an increase in $\eta$ lowers $\operatorname{Prob}\{\bar{\beta} \geq 1\}$ and raises $\operatorname{Prob}\left\{\beta_{t}^{*}=1\right\}$ only when $\lambda$ is relatively large, as shown in appendix A. Therefore, the net effect of $\eta$ on $\operatorname{Prob}\left\{\beta^{*}=1\right\}$ is likely to be negative. The same is true about an increase in $\nu$, which lowers $\operatorname{Prob}\left\{\beta_{t}^{*}=1\right\}$ but has an ambiguous effect on $\operatorname{Prob}\{\bar{\beta} \geq 1\}$.

Table 2 summarizes these results. Although there are some ambiguities in the model's predictions regarding the impact of $\eta$ and $v$ on equity structure, it still has testable

\footnotetext{
${ }^{23}$ For example, according to the 1982 Benchmark Survey, only about $4 \%$ of U.S. TNEs faced equity restrictions.
}

TAble 2.-Theoretical Impact of the Model's Parameters ON EQUilibrium EQuity STRUCTURE

\begin{tabular}{lcccccc}
\hline \hline Parameters & $\eta$ & $\lambda$ & $\nu$ & $\tau$ & $\mu$ & $\rho$ \\
\hline $\operatorname{Prob}\left\{\beta^{*}=1\right\}$ & $-?$ & + & $-?$ & + & + & - \\
$E\left(\beta^{*}\right)$ & $-?$ & + & - & + & + & $-?$ \\
\hline
\end{tabular}

implications concerning the variables determining these parameters. Specifically, the model implies that the direction in which each one of those variables affects $\beta^{*}$ and $\operatorname{Prob}\left\{\beta^{*}=1\right\}$ should be the same.

\section{Econometric Specification}

In this section, we discuss the determinants of $\eta, \lambda, \nu, \tau$, $\mu$, and $\rho$. We consider variables that are clearly implied by our model as well as variables that have been widely discussed in the literature. We reinterpret the latter in light of our model, establishing their "plausible" relationships with equity structure. We recognize that there are alternative explanations for the roles of both groups. We point out these alternatives as we discuss our results and assess them vis-à-vis the implications of our model. We do not claim to have accounted for all possible factors, and not all our prior conjectures prove correct. However, the exercise helps identify important variables and mechanisms at work.

In our estimations, each observation represents a subsidiary of a U.S.-based TNE in a foreign country. The dependent variable, EQUITY, is the share of equity in the subsidiary owned by the U.S. parent, which takes on values between 0 and 1 . In the analysis of joint ventures $(E Q U I T Y<1)$, we treat $E Q U I T Y$ as a continuous variable. In the context of the choice between whole and joint ownership, EQUITY will be treated as a dichotomous variable that equals 1 if ownership is full and 0 if there is any sharing. Because in both situations the relevant variables generally affect foreign equity in the same direction, we economize in the discussion by examining how various variables affect EQUITY without specifying the choice, unless it is unclear from the context.

The data on EQUITY and firm characteristics were obtained from the 1997 Directory of Corporate Affiliates and refer to firms active in 1996. Industry data were obtained from the Benchmark Survey Results published by the U.S. Department of Commerce. Data on country characteristics were obtained from various sources and measured as averages for the prior ten to fifteen years, depending on data availability. Appendix B describes the data and provides references for the sources.

\section{A. Firm Characteristics}

The discussion in section III indicates that any factor that increases the range and productivity of a TNE's assets raises $\lambda$ and should be positively related to EQUITY. Furthermore, firm characteristics that affect a TNE's relative disadvantage in procuring local assets, $\rho$, will have a negative impact on 
EQUITY. Below, we discuss the variables that underlie $\lambda$ and $\rho$.

TNE Noncontractible Assets: An important role of a TNE is to supply its intangible and noncontractible assets to an FDI project. To measure the productivity of these assets, we use the ratio of sales to tangible assets $(S A L) .{ }^{24}$ Because tangible assets are often included in a firm's balance sheet whereas the intangible assets are not, $S A L$ can act as an indicator of the firm's richness in intangible assets, which tends to raise $\lambda .^{25}$

In the FDI literature, the ratio of R\&D and advertising expenditures to sales are often used as alternative measures of intangible assets. However, these measures fail to account for many intangible assets such as management and marketing skills. This is true even for technology and brand-name assets accumulated through R\&D and advertising if there is not a sufficiently long time series for the latter variable. In our sample, data on R\&D and advertising expenditures are missing for many firms. The results for the limited sample suggest the superiority of $S A L$. We also use the industry R\&D-sales ratio. This variable performs better, but it is an industry rather than a firm characteristic, which we discuss later.

TNE Size and Other Capability Indicators: A number of authors have observed that smaller TNEs tend to take a lower equity position in their foreign subsidiaries. This relationship, which is known as the "Wells effect," has been attributed to the special needs of small TNEs and their more limited intangible assets (Stopford \& Wells, 1972). The latter explanation is consistent with our model. We include the logs of the total employment and sales of the TNE in our regressions to test whether firm size has any effect on EQUITY beyond the effects captured by SAL.

Another indicator of a TNE's capabilities is public trading of its stock (PUBTRADE). Publicly traded firms must have proven capabilities to maintain substantial specific assets. Moreover, access to equity markets lowers the cost of capital and allows the TNE to satisfy a wider range of project needs. If PUBTRADE $=1$ when a TNE's stock is traded and 0 otherwise, EQUITY should rise with PUBTRADE.

Parent Diversity: Although a TNE may be well endowed in intangible assets, its role in its subsidiaries may be small if its assets are spread over a wide range of industries.

\footnotetext{
${ }^{24}$ We recognize that using value added in place of sales would have been preferable. However, data on value added is available for only a limited subset firms in our sample.

${ }^{25}$ Note that $S A L$ increases with labor intensity. Hence, the relationship between $S A L$ and EQUITY may be influenced by any role that labor intensity plays in ownership decisions. To control for this factor, we included the TNE asset-employment ratio in our regressions, which proved insignificant. To separate the possible effects of firm size from that of intangible assets, we also included total TNE sales and employment, both of which were insignificant.
}

Thus, a parent involved in too many industries is less likely to contribute much to the operation of each subsidiary. To capture this effect, we supplement the sales-asset ratio with another variable, DIVERSE, which is the number of fourdigit products that the parent manufactures. The hypothesis is that DIVERSE is negatively related to EQUITY. ${ }^{26}$

\section{International Experience: Anderson and Gatignon} (1988) argue that firms with more international experience may be more adept in monitoring and dealing with local employees, and consequently less likely to rely on a local partner. ${ }^{27}$ Davidson and McFetridge $(1984,1985)$, on the other hand, argue that international experience fosters joint ventures because experienced firms are able to monitor their partners more effectively. However, it is not clear a priori why international experience should give TNEs an advantage in dealing with the locals as partners rather than as employees, or vice versa. Our model's implications about the role of TNE experience are closer to the former view: international experience, especially the duration of exposure to a host country's conditions, increases the local knowledge and connections of the TNE. This reduces the comparative advantage of the local entrepreneurs, $\rho$, and raises EQUITY. Erramilli (1991) ascribes the conflicting findings in the literature to the diminishing effects of experience. This calls for a quadratic specification, which we adopt. Following the literature, we measure experience by the age of the TNE $(A G E)$ and the number of its foreign subsidiaries $\left(\right.$ SUBNUM) ${ }^{28}$

Note that $S U B N U M$ may also represent effects other than experience. In particular, it may reflect the aspects of a firm's activity that lack economies of scale and require localized production. Involvement in many projects may also spread the firm's managerial resources more thinly over subsidiaries, which may increase the need for more local inputs. Both of these effects tend to increase $\rho$ or $v$ and, therefore, counteract any positive contribution by the scope of international experience to the TNE's comparative advantage. Therefore, the relationship of SUBNUM with EQUITY is theoretically ambiguous.

\footnotetext{
${ }^{26}$ Gomes-Casseres (1989) uses a different measure of diversity, namely, a dummy variable that takes on value 1 if the affiliate is in a different industry than the parent and concludes that diversity encourages sharing.

${ }^{27}$ See also Hennart (1991) and Gomes-Casseres (1989). Johanson and Vahlne (1977) and Davidson (1982) offer a somewhat different argument for a positive relationship between a TNE's international experience and its share in its subsidiaries: less-experienced firms perceive considerable uncertainty, overstate risks, and understate returns. Thus, they are less likely to make significant resource commitments and assume control. With increasing experience, firms acquire knowledge of foreign markets and are better able to assess risks and returns and manage foreign operations.

${ }^{28}$ We have data on the age of the parent company, but not on how long it has been a TNE. However, these two variables are likely to be closely correlated. Also, note that country conditions around the world have become more favorable for whole ownership over time. Therefore, older TNEs are likely to have more joint ventures. The estimated coefficient of AGE includes this effect, if it exists.
} 
Organizational Structure: Some TNEs form regional headquarters to decentralize control over their subsidiaries. The advantages of a regional headquarters are that the TNE becomes more familiar with local conditions and it helps reduce the need for local entrepreneurs (lower $\rho$ ). Thus, firms with regional headquarters should have a higher equity in their subsidiaries. To capture this organizational feature, we use a dummy variable (REGIONAL) that takes on value 0 if the subsidiary reports directly to the U.S. parent and 1 if it reports to a decentralized headquarters. It is possible that the existence of a regional headquarters reflects a need for effective coordination of a number of subsidiaries in the same region. This should strengthen the TNE's preference for whole ownership as a way of minimizing conflicts that may delay decision making in joint ventures. Our model does not capture this effect, but, because the effect works in the same direction as the effect predicted by the model, the coefficient of REGIONAL in the regressions may be interpreted as a joint measure of both effects.

\section{B. Industry Characteristics}

Whereas firm characteristics measure the assets of the TNE that contribute to an FDI project, industry characteristics indicate the importance of these assets for the project. In this sense, industry characteristics may affect all the production parameters.

Technology Intensity: Besides reflecting firm assets, $\lambda$ captures the importance of nonmarketable technological know-how in the industry. Following the literature, we use the ratio of $R \& D$ expenditure to sales as a proxy for technology intensity. Our analysis predicts a positive coefficient for this variable.

Resource Intensity: A number of studies have argued that TNEs in resource-based industries may give up control in order to gain access to raw material sources (Stopford \& Wells, 1972; Gomes-Casseres, 1989). This argument is valid if TNEs cannot easily acquire natural resources through competitive markets and have less access to those resources compared to local firms. In the context of our model, this implies higher $v$ and $\rho$ and, hence, a lower EQUITY. Note that the importance of natural resources for generating rents also raises the role of the host country's assets, which translates into a higher $\eta$. This effect is likely to lower the equilibrium EQUITY because, despite the TNE's increased interest in capturing the rents through a larger equity share, the host government would be keen to retain their natural resource rents, especially because such resources are often publicly owned. ${ }^{29}$

\footnotetext{
${ }^{29}$ The rents in natural resource-based projects appear to be substantial:
} the return on US FDI in petroleum projects in 1993 averaged 23\%
To examine the relationship between EQUITY and the importance of natural resources in the industry, we follow Hennart (1991) and Gomes-Casseres (1989) and use a dummy for the set of industries that they identify as "resource-based" manufacturing (RESBASED). ${ }^{30} \mathrm{We}$ also include a dummy for petroleum, coal, and mining (PETMIN), which are not included in RESBASED. The preceding discussion suggests that both dummies should have negative effects on EQUITY. Although this is confirmed in our regressions, our model suggests that the contribution of the country's resources to the specific rents of the FDI project matters particularly. If a natural resource can be easily sold on the market, it may not contribute much to the surplus of the project. To examine this refined hypothesis, we interact RESBASED and PETMIN with the degree of backward vertical integration in the industry $(B V E R T)$, which we define for each industry as the share of the parent firms' imports supplied by their subsidiaries. If TNEs in an industry buy most of their imports from their subsidiaries, direct access to the resources through arm's-length transactions must be costly and, hence, the resources must be generating more rents in the subsidiaries. Our analysis suggests that the two interactive terms should account for the bulk of the negative relationship between their corresponding industry dummies and EQUITY.

Environmentally costly industries can also be considered resource intensive. In our data set, chemical industries are environmentally costly and are not included in RESBASED and PETMIN. We include dummies for these industries and interact those dummies with $B V E R T$, expecting them to have negative coefficients.

Vertical Integration: As discussed previously, TNEs are more likely to engage in backward integration when subsidiaries have access to resources that are costly to transact on the market. For an industry as a whole, such vertical integration implies the importance of country assets for the project's output and surplus generation. Hence, BVERT is positively associated with $\eta$ and should, therefore, have a negative effect on EQUITY. Of course, the natural resource dummies and their interaction terms capture part of this effect, and their presence in the regression may take away significance from $B V E R T$.

Similarly, forward vertical integration (FVERT), measured by the share of total sales of U.S. TNEs in each industry exported to their subsidiaries, should be positively related to EQUITY. A high FVERT is an indication that the role of nonmarketable TNE assets in the industry's production is important, which implies a higher $\lambda$ and, thus, a higher EQUITY. Note that FVERT may also reflect the importance of industry intangible assets.

\footnotetext{
compared with $14 \%$ for manufacturing projects and $16 \%$ for trade, banking, and other services.

${ }^{30}$ The dummy variable equals one if the subsidiary's main product is in one of the following industries: food and beverages, tobacco, textile, mills, wood except furniture, pulp and paper, rubber, and primary metals.
} 
Other Effects and Industry Dummies: Besides the variables discussed, there are other industry characteristics that may influence EQUITY, but we do not have measures for them. For example, $v$ should be higher for the so-called market-seeking industries in which production units mainly serve local markets. Examining this effect requires data on the share of local sales in each industry, which is unavailable. We use one- and two-digit SIC-level industry dummies to account for such effects. We expect the dummies for market-seeking industries such as food and bakery to have negative coefficients. Industries such as electronic and electrical equipment, on the other hand, can more easily serve distant markets. Therefore, their dummies should have positive coefficients. ${ }^{31}$

\section{Country Characteristics}

In this subsection, we examine the relationship of country characteristics with $\eta, \nu, \rho, \tau$, and $\mu$.

Country Resources and Institutions: Reliability of institutions, physical infrastructure, attractiveness of markets, and growth potential are country-specific assets that enhance the productivity of FDI projects. An increase in such factors implies a higher $\eta$ and, therefore, a lower EQUITY. To measure infrastructure availability, we use the number of telephones per 1,000 population. For institutional reliability, we employ the survey-based indicator of rule of law from the ICRG data set. ${ }^{32}$ We use total GDP, GDP growth rate, and the share of investment in GDP to proxy for market size and growth potential.

Local Knowledge and Connections: We include five types of variables that may influence the local's comparative advantage in providing local knowledge and connections.

First, we use an indicator of the share of black market in the economy $(B L A C K)$ to measure the degree of distortion in the economy. Firms that operate in countries with a large

\footnotetext{
${ }^{31}$ In addition to the industry variables discussed in the text, we considered the role of capital intensity. A number of studies have suggested that TNEs investing in projects with greater capital requirements are more vulnerable to contractual hazards and, therefore, try to mitigate the problem by maintaining full control of the subsidiary (Henisz, 1997). This argument has two shortcomings. First, the contractual hazards of obtaining local inputs are unlikely to disappear by recruiting the providers of those inputs as employees rather than partners. Second, it is not clear why, in the presence of investment risk, a TNE should take a majority position rather than reducing its investment level. In the context of our model, it is possible that capital intensity may be related to the foreign share if TNEs have an advantage in supplying capital. However, the proxies we used for this purpose, particularly the TNE's asset-employment ratio, did not show much significance. Some authors have used the firm-level sales-asset ratio $(S A L)$ for this purpose. But, as we have argued, $S A L$ has a better interpretation and carries a different sign in the regressions than the capital intensity hypothesis suggests.

32 Another measure of institutional reliability that may facilitate the formation of joint ventures is intellectual property protection (IPP) (cf., Lee and Mansfield (1996) and Kumar (1996))). We do not have data on IPP for our sample. However, the measure of rule of law should be closely related to IPP. We also experimented with different measures of political instability, but the results proved unstable.
}

black market are more likely to encounter hassles in their transactions. In such environments, an influential local partner can more effectively provide access to "special" treatment. Thus, BLACK should be negatively related to EQUITY. Corruption may also motivate joint ventures for similar reasons. However, this variable may work both ways. Although corruption may imply the importance of personal relations rather than rules, it may also help TNEs to simply pay off bureaucrats and policymakers directly without having to know the details of the rules and regulations. We examined the role of corruption but did not find it significant.

Second, in countries where the risk of nationalization is high, local partners can play a crucial role in mitigating the government's hostile acts. The ICRG data set includes a measure of "nationalization safety," which we expect to have a positive sign when included as an explanatory variable for EQUITY.

Third, we include in the model the per capita years of schooling in the country and the share of nonagricultural sectors in the economy-wide employment. The more educated the labor force and the larger the pool of nonagricultural workers, the easier it should be for a TNE to communicate with the labor force and customers of its subsidiaries. Hence, greater education and a larger nonagricultural labor force should reduce the need to recruit and motivate local partners for intermediation.

Fourth, we use dummy variables to capture the effect of sociocultural distance between the United States and the host country. Operating in a dissimilar culture raises the costs of acquiring information to monitor and evaluate business activities. This raises the comparative advantage of local entrepreneurs and, hence, should lower EQUITY (Anderson \& Gatignon, 1988). We use dummy variables to identify five groups of countries: countries with British cultural heritage $(A N G L O)$, non-Anglo European (EUROPE), Latin American (LATIN), Asian (ASIA), and the rest. ${ }^{33}$ We hypothesize that U.S. firms are less likely to need local partners with large shares when they operate in Western cultures (ANGLO, EUROPE, and LATIN).

Finally, we introduce openness of the host economynamely, the ratio of trade to GDP - as an indicator of ease of access to inputs. When subsidiaries can easily import and export, they are less likely to have to deal with problematic local inputs. Hence, openness should be positively related to EQUITY.

Technological Capabilities of Domestic Firms: The inputs from local entrepreneurs may include commercial experiences or technological capabilities that are complementary to those of the TNE (Gomes-Casseres, 1990). Such variables tend to raise $v$ and should be negatively related to

\footnotetext{
${ }^{33}$ We also used the indicators of legal origins proposed by LaPorta et al. (1999) as alternative measures of the cultural distance between the United States and the host countries, but the variables proved insignificant.
} 
EQUITY. To measure this effect, we use the share of domestic firms in the total number of patents granted in each host country (PATENT). A higher share indicates greater local capability and should be associated with lower EQUITY. ${ }^{34}$

FDI Policy of the Host Government: As pointed out earlier, we use the percentage of U.S. parent firms in each host country that were asked to limit their equity in their subsidiaries, RESTRICT, as a measure of the restrictiveness of policy and expect it to affect EQUITY negatively. ${ }^{35}$ The data comes from the 1982 Benchmark Survey of the U.S. Department of Commerce, which is the most recent survey available with information about ownership restriction. ${ }^{36}$ Although 1982 data may seem too old for predicting ownership structure in 1996, it should be kept in mind that the subsidiaries have been formed over a long period and that the equity structure of established firms respond very slowly to changes. Moreover, perceptions and policies tend to last and investments take time to mature. As a result, the 1982 policy data cannot be dismissed as outdated. ${ }^{37}$

\section{The Econometric Model}

The econometric model that our theoretical framework implies is a variant of the tobit model analyzed by Cragg (1971). The model can be specified as

$$
\begin{array}{ll}
y=\varphi X+\epsilon & \\
E Q U I T Y=1 & \text { if } \quad y \geq 1 \text { and } \\
\text { EQUITY }=\gamma Z+\epsilon^{\prime} & \text { if } \quad y<1,
\end{array}
$$

where $y$ is a latent variable,

$\epsilon$ and $\epsilon^{\prime}$ are normally distributed random variables,

$X$ and $Z$ are vectors of the explanatory variables, and

\footnotetext{
${ }^{34}$ We obtained similar results using the share of firms from each host country in the total patents granted in the United States.

${ }^{35}$ Note that RESTRICT may depend on country characteristics. This should not bias the coefficient of RESTRICT because we include a host of relevant country characteristics in the model. Therefore, only the residual role of RESTRICT that represents policy is likely to be reflected in its coefficient.

${ }^{36}$ Data on FDI restrictions were not collected during the most recent Benchmark Survey in 1994. Further, the unpublished data for the 1989 survey was deemed unreliable by the Department of Commerce.

${ }^{37}$ Another potential disadvantage of RESTRICT is that it may not capture the cases of severe restriction that discourage TNEs from entering the host country. For example, a very restrictive country may end up with a low RESTRICT index if only a few firms that somehow gain exemption from equity restrictions find it worthwhile to enter. As a result, there may be some error in the measurement of policy restrictiveness. We employ RESTRICT in our regressions because, despite its limitations, it performs better than other measures of restrictiveness used in previous studies. Past studies have often used a dummy variable to capture restrictive countries. Erramilli (1996) and Contractor (1991) use a performance index. This index turned insignificant in our regressions when country variables were included. We also used a policy restrictiveness variable computed by Henisz (1997), but it was insignificant.
}

$\varphi$ and $\gamma$ are vectors of parameters to be estimated.

In a tobit model, $X=Z$ and $\varphi=\gamma$. However, our earlier discussions suggest that the set of variables that affect the choice of whole versus joint ownership may not be the same as the one determining $E\left(\beta^{*}\right)$ in joint ventures, and even the variables that are common may not have the same impacts. As it stands, this model can be estimated in two parts by using a probit procedure for the discrete choice between whole and joint ownership and a truncated regression model for the joint venture observations. This is the procedure that we follow.

\section{Estimation Results}

Past empirical work on the cross-country variation of equity share in FDI projects has focused on manufacturing. ${ }^{38}$ In this study, we consider non-bank parents and their non-bank subsidiaries, which comprise firms in finance (such as insurance, real estate and holding companies, and other nondepository institutions), services, wholesale and retail trade, manufacturing, extractive industries, and agriculture. We have data on EQUITY for 4,430 non-bank subsidiaries, but firm, industry, and country data for these observations are not complete. Our probit regressions typically use 2,416 observations from 305 U.S. parent TNEs in 42 countries. Approximately $14 \%$ of all samples that we use in our regressions are joint ventures. ${ }^{39}$ The truncated regressions for joint ventures are based on 331 observations. Summary statistics of the variables are compiled in table 3.

Table 4 presents the main results for the probit model. Column 1 is a basic version in which we include all of the variables whose coefficients are relatively robust in terms of magnitude and statistical significance to variations in specification. The evidence of the robustness of the model to sample changes is shown in columns 2,3 , and 4 , where the basic regression is run with three subsamples: nonservice and nonfinance, nonwholesale, and manufacturing. The results show a remarkable degree of consistency across samples and specifications, with the coefficients of the variables carrying their expected signs.

TNE characteristics measured by SAL, AGE, DIVERSE, $P U B T R A D E$, and REGIONAL perform quite well in the regressions. The fact that the sales-asset ratio remains highly significant after controlling for a host of effects lends credence to our claim that it is a good measure of intangible assets. The AGE-EQUITY relationship turns out to be quadratic, with a positive derivative throughout the sample

\footnotetext{
${ }^{38}$ Few studies venture to study other sectors. Among them, Erramilli (1996) examines ownership decisions of TNEs in the advertising industry.

${ }^{39}$ This is less than the share of joint ventures in all U.S. non-bank foreign subsidiaries, which in the mid-1990s was about 20\% (cf., Survey of Current Business (June 1995)). However, this does not seem to introduce a sampling bias because our results did not change in any substantial way in a series of experiments in which we randomly eliminated part of the fully owned subsample to make its proportion similar to that of the total population.
} 
Table 3.-Summary Statistics for the Full Sample (2,416 Subsidiaries)

\begin{tabular}{|c|c|c|c|c|}
\hline Variables & Mean & Standard Deviation & Minimum & Maximum \\
\hline Share of equity owned by TNE & 0.950 & 0.151 & 0.100 & 1.000 \\
\hline \multicolumn{5}{|l|}{ Firm Characteristics } \\
\hline Log (TNE sales/assets) & 0.167 & 0.392 & -2.180 & 2.026 \\
\hline Age of $\mathrm{TNE}^{\mathrm{a}}$ & 72.804 & 42.092 & 1.00 & 230 \\
\hline $\log (1+$ number of foreign subsidiaries $)$ & 2.870 & 1.034 & 0.693 & 4.727 \\
\hline Production diversity of $\mathrm{TNE}^{\mathrm{b}}$ & 4.976 & 3.021 & 1.00 & 10.0 \\
\hline \multicolumn{5}{|l|}{ Industry Characteristics } \\
\hline $100^{*}$ (research expenditure/sales) & 4.448 & 3.533 & 0.008 & 11.985 \\
\hline Backward vertical integration $^{\mathrm{c}}$ & 0.525 & 0.216 & 0.067 & 0.964 \\
\hline Forward vertical integration $^{\mathrm{d}}$ & 0.481 & 0.197 & 0.043 & 0.869 \\
\hline \multicolumn{5}{|l|}{ Country Characteristics } \\
\hline Equity restrictions ${ }^{\mathrm{e}}$ & 4.098 & 8.360 & 0 & 53.571 \\
\hline Share of patents granted to local firms & 0.187 & 0.194 & 0.004 & 0.849 \\
\hline Log (number of phones per 1,000 population) & 6.826 & 0.748 & 2.051 & 7.437 \\
\hline Log (average years of schooling) & 2.106 & 0.304 & 1.218 & 2.576 \\
\hline Share of non-agricultural sector employment & 0.888 & 0.127 & 0.24 & 0.98 \\
\hline Rule of law ${ }^{\mathrm{f}}$ & 5.106 & 1.030 & 1.25 & 6 \\
\hline Risk of expropriation ${ }^{\mathrm{g}}$ & 9.183 & 1.038 & 5.22 & 9.98 \\
\hline Black market ${ }^{\mathrm{h}}$ & 1.554 & 1.028 & 1 & 5 \\
\hline
\end{tabular}

${ }^{a}$ Number of years since the parent company was established.

${ }^{\mathrm{b}}$ Number of four-digit product lines that TNE manufactures.

c The share of U.S. parent firms' imports supplied by their subsidiaries.

'The share of U.S. parent firms' exports that is supplied to their subsidiaries.

e The 1982 Benchmark Survey measure of the percentage of U.S. parent firms in each host country that were asked to limit their equity in their foreign subsidiaries

${ }^{\mathrm{f}}$ ICRG indicator for the degree to which the citizens of a country are willing to accept the established institutions to make and implement laws and adjudicate disputes. Higher scores indicate sound political institutions, a strong court system, and provisions for an orderly succession of power. Lower scores indicate a tradition of depending on physical force or illegal means to settle claims. Range 0 to 6 .

$\mathrm{g}$ ICRG indicator for the assessed risk of outright confiscation or forced nationalization. Lower scores indicate higher risks. Range 0 to 10 .

h Johnson and Sheehy's (1996) indicator of the share of blank market in the economy, ranges from 1 (less than 10\%) to 5 (greater than $30 \%$ ).

range. The relationship of the log of number of subsidiaries (SUBNUM) with EQUITY is also quadratic, but its derivative is positive only when $S U B N U M$ is relatively small. This finding suggests that $S U B N U M$ mainly reflects the localized nature of production rather than the asset value of the TNE's international experience. The signs of REGIONAL and PUBTRADE confirm that decentralized organization and other capabilities of a TNE enable it to maintain larger shares in its subsidiaries. Finally, our data do not support the Wells Effect because, once we control for other factors, all measures of TNE size prove insignificant.

Among industry-level variables, natural resource dependence and vertical integration variables proved quite significant. In particular, the interactions between natural resource dummies (RESBASED and PETMIN) and backward integration (BVERT) have strong negative relationships with the probability of whole ownership. PETMIN and BVERT are not shown in table 4 because they proved insignificant. However, if the interaction terms are removed, these variables-as well as RESBASED-all carry significant negative coefficients. (These results are not shown here.) This confirms the implication of our model that the inverse relationship between backward integration and EQUITY can be attributed to the importance of the host country's "costlyto-transact" resources in generating rents.

The R\&D-sales ratio has the expected positive sign in all regressions, but its significance is marginal, and, in some subsamples, it turns insignificant. However, it becomes consistently positive and significant when the forward integration measure (FVERT) is omitted from the regressions. This indicates the presence of a multicollinearity problem that is confirmed by the high correlation coefficient of the $\mathrm{R} \& \mathrm{D}$-sales ratio and FVERT, which is greater than 0.5 in all samples. ${ }^{40}$ These observations support our view that forward vertical integration reflects the importance of TNE intangible assets in an industry, including the products of R\&D. It is worth noting that the opposite effects we find for the backward and forward integration variables suggest that using an overall measure of vertical integration, such as intra-system sales, to determine the relationship between equity share and vertical integration (as done in a number of other studies), would produce misleading results. The finding also challenges the view that vertical integration raises the probability of whole ownership because intra-system sales generate conflict between joint venture partners over transfer prices.

The dummy variables for industrial and other chemical products have negative effects on the probability of whole ownership, reflecting their environmental consequence as a natural resource base. The coefficient of the dummy for grain, milling, and bakery products is also negative, indicating the importance of local markets in those industries. (It is possible that the negative effect of these industries is also due to reliance on natural resources.) In contrast, industries wholesaling professional and commercial equipment and producing electronic components and accessories show positive effects. Note that all these effects obtain after

\footnotetext{
40 This may explain the insignificance of the coefficient of R\&D-sales ratio in a number of other studies that include forward integration measures as well (such as Gomes-Casseres (1990)).
} 
Table 4.-The Probit Model: Determinants of the Choice Between Whole and Joint Ownership by U.S. Non-Bank TNEs

\begin{tabular}{|c|c|c|c|c|}
\hline Variables & $\begin{array}{c}(1) \\
\text { All Industries }\end{array}$ & $\begin{array}{l}\text { (2) } \\
\text { All Industries Except } \\
\text { Finance and Service }\end{array}$ & $\begin{array}{c}\text { (3) } \\
\text { All Industries } \\
\text { Except Wholesale }\end{array}$ & $\begin{array}{c}(4) \\
\text { Manufacturing }\end{array}$ \\
\hline Intercept & $\begin{array}{c}0.232 \\
(0.727)\end{array}$ & $\begin{array}{c}0.673 \\
(0.469)\end{array}$ & $\begin{array}{c}1.291 \\
(0.194)\end{array}$ & $\begin{array}{c}1.857 \\
(0.143)\end{array}$ \\
\hline \multicolumn{5}{|l|}{ Firm Characteristics } \\
\hline Log (TNE sales/assets) & $\begin{array}{l}0.351 * * * \\
(0.001)\end{array}$ & $\begin{array}{l}0.346^{* * * *} \\
(0.002)\end{array}$ & $\begin{array}{l}0.510 * * * \\
(.000)\end{array}$ & $\begin{array}{l}0.492 * * * \\
(0.001)\end{array}$ \\
\hline$($ Age of TNE)/100 & $\begin{array}{l}0.906 * * * \\
(0.001)\end{array}$ & $\begin{array}{l}0.888^{* * * *} \\
(0.001)\end{array}$ & $\begin{array}{l}0.993 * * * \\
(0.001)\end{array}$ & $\begin{array}{c}0.623^{*} \\
(0.082)\end{array}$ \\
\hline (Age of TNE)/100 squared & $\begin{array}{c}-0.403 * * * \\
(0.003)\end{array}$ & $\begin{array}{c}-0.414 * * * \\
(0.003)\end{array}$ & $\begin{array}{c}-0.427 * * * \\
(0.004)\end{array}$ & $\begin{array}{c}-0.277 * \\
(0.098)\end{array}$ \\
\hline $\log (1+$ number of foreign subsidiaries $)$ & $\begin{array}{l}0.415 * * \\
(0.023)\end{array}$ & $\begin{array}{c}0.320^{*} \\
(0.090)\end{array}$ & $\begin{array}{c}0.342 \\
(0.104)\end{array}$ & $\begin{array}{c}0.143 \\
(0.554)\end{array}$ \\
\hline $\log (1+$ number of foreign subsidiaries $)$ squared & $\begin{array}{c}-0.079 * * \\
(0.012)\end{array}$ & $\begin{array}{c}-0.064^{* * *} \\
(0.049)\end{array}$ & $\begin{array}{r}-0.067^{*} \\
(0.062)\end{array}$ & $\begin{array}{r}-0.030 \\
(0.459)\end{array}$ \\
\hline Production diversity of TNE & $\begin{array}{c}-0.044 * * * \\
(0.002)\end{array}$ & $\begin{array}{c}-0.037 * * \\
(0.012)\end{array}$ & $\begin{array}{c}-0.067 * * * \\
(0.000)\end{array}$ & $\begin{array}{l}-0.060 * * * \\
(0.001)\end{array}$ \\
\hline Organizational structure dummy ${ }^{\mathrm{a}}$ & $\begin{array}{c}0.230^{*} \\
(0.095)\end{array}$ & $\begin{array}{c}0.249 * \\
(0.077)\end{array}$ & $\begin{array}{l}0.369 * * \\
(0.024)\end{array}$ & $\begin{array}{l}0.388^{* * *} \\
(0.030)\end{array}$ \\
\hline Public trading dummy ${ }^{\mathrm{b}}$ & $\begin{array}{l}0.733^{* * *} \\
(0.001)\end{array}$ & $\begin{array}{l}0.598 * * * \\
(0.010)\end{array}$ & $\begin{array}{l}0.998 * * * \\
(0.000)\end{array}$ & $\begin{array}{l}0.852 * * * \\
(0.001)\end{array}$ \\
\hline \multicolumn{5}{|l|}{ Industry Characteristics } \\
\hline Research expenditure/sales & $\begin{array}{c}0.027 * \\
(0.068)\end{array}$ & $\begin{array}{c}0.017 \\
(0.297)\end{array}$ & $\begin{array}{l}0.038 * * \\
(0.021)\end{array}$ & $\begin{array}{c}0.020 \\
(0.295)\end{array}$ \\
\hline RESBASED ${ }^{\mathrm{c}}$ & $\begin{array}{l}0.844 * * * \\
(0.001)\end{array}$ & $\begin{array}{l}0.877 \text { *** } \\
(0.000)\end{array}$ & $\begin{array}{l}0.881 \text { *** } \\
(0.001)\end{array}$ & $\begin{array}{l}0.926 * * * \\
(0.000)\end{array}$ \\
\hline Forward vertical integration & $\begin{array}{l}0.555 * * \\
(0.034)\end{array}$ & $\begin{array}{l}0.819 \text { *** } \\
(0.005)\end{array}$ & $\begin{array}{c}0.475 \\
(0.133)\end{array}$ & $\begin{array}{l}0.984 * * \\
(0.011)\end{array}$ \\
\hline PETMIN *BVERT ${ }^{\mathrm{d}}$ & $\begin{array}{c}-1.110^{*} \\
(0.056)\end{array}$ & $\begin{array}{c}-1.004 * \\
(0.089)\end{array}$ & $\begin{array}{c}-1.201 * \\
(0.053)\end{array}$ & \\
\hline$R E S B A S E D * B V E R T^{\mathrm{e}}$ & $\begin{array}{l}-2.239 * * * \\
(0.000)\end{array}$ & $\begin{array}{c}-2.251 \text { *** } \\
(0.000)\end{array}$ & $\begin{array}{c}-2.276^{* * * *} \\
(0.000)\end{array}$ & $\begin{array}{c}-2.215^{* * *} \\
(0.000)\end{array}$ \\
\hline \multicolumn{5}{|l|}{ Industry Dummies } \\
\hline Manufacturing & $\begin{array}{c}-0.274 * * \\
(0.012)\end{array}$ & $\begin{array}{c}-0.243^{* *} \\
(0.036)\end{array}$ & $\begin{array}{c}-0.332^{* *} \\
(0.031)\end{array}$ & \\
\hline Grain and bakery products & $\begin{array}{c}-0.673 * * \\
(0.015)\end{array}$ & $\begin{array}{c}-0.677^{* *} \\
(0.015)\end{array}$ & $\begin{array}{c}-0.680^{* *} \\
(0.016)\end{array}$ & $\begin{array}{c}-0.631 * * \\
(0.027)\end{array}$ \\
\hline Industrial chemicals & $\begin{array}{l}-0.684 * * * \\
(0.000)\end{array}$ & $\begin{array}{c}-0.657 * * * \\
(0.000)\end{array}$ & $\begin{array}{c}-0.634 * * * \\
(0.000)\end{array}$ & $\begin{array}{l}-0.563 * * * \\
(0.000)\end{array}$ \\
\hline Chemical products & $\begin{array}{c}-0.344 * * \\
(0.036)\end{array}$ & $\begin{array}{c}-0.302^{*} \\
(0.066)\end{array}$ & $\begin{array}{c}-0.329 * * \\
(0.049)\end{array}$ & $\begin{array}{r}-0.226 \\
(0.183)\end{array}$ \\
\hline Electronic components & $\begin{array}{l}0.365 * * \\
(0.034)\end{array}$ & $\begin{array}{l}0.385^{* * *} \\
(0.026)\end{array}$ & $\begin{array}{l}0.344 * * \\
(0.049)\end{array}$ & $\begin{array}{l}0.358 * * \\
(0.043)\end{array}$ \\
\hline Commercial equipment ${ }^{\mathrm{f}}$ & $\begin{array}{l}0.525 * * \\
(0.035)\end{array}$ & $\begin{array}{l}0.610 * * \\
(0.019)\end{array}$ & & \\
\hline \multicolumn{5}{|l|}{ Country Characteristics } \\
\hline Equity restrictions & $\begin{array}{c}-0.025^{* * * *} \\
(0.000)\end{array}$ & $\begin{array}{c}-0.029 * * * \\
(0.000)\end{array}$ & $\begin{array}{c}-0.027 * * * \\
(0.000)\end{array}$ & $\begin{array}{c}-0.025^{* * *} \\
(0.001)\end{array}$ \\
\hline Black market & $\begin{array}{l}-0.358 * * * \\
(0.000)\end{array}$ & $\begin{array}{c}-0.363 * * * \\
(0.000)\end{array}$ & $\begin{array}{l}-0.409 * * * \\
(0.000)\end{array}$ & $\begin{array}{c}-0.425 * * * \\
(0.000)\end{array}$ \\
\hline Risk of expropriation & $\begin{array}{c}0.197 * \\
(0.080)\end{array}$ & $\begin{array}{c}0.172 \\
(0.133)\end{array}$ & $\begin{array}{c}0.123 \\
(0.332)\end{array}$ & $\begin{array}{c}0.088 \\
(0.536)\end{array}$ \\
\hline Log (average years of schooling) & $\begin{array}{l}0.734 * * * \\
(0.006)\end{array}$ & $\begin{array}{l}0.714 \text { *** } \\
(0.008)\end{array}$ & $\begin{array}{c}0.564 * \\
(0.053)\end{array}$ & $\begin{array}{c}0.374 \\
(0.262)\end{array}$ \\
\hline Share of nonagricultural sector employment & $\begin{array}{l}0.012 * * \\
(0.046)\end{array}$ & $\begin{array}{l}0.013^{* *} \\
(0.039)\end{array}$ & $\begin{array}{c}0.008 \\
(0.221)\end{array}$ & $\begin{array}{c}0.013 \\
(0.124)\end{array}$ \\
\hline Share of patents granted to local firms & $\begin{array}{l}-1.450 * * * \\
(0.000)\end{array}$ & $\begin{array}{c}-1.348 * * * \\
(0.000)\end{array}$ & $\begin{array}{c}-1.409 * * * \\
(0.000)\end{array}$ & $\begin{array}{c}-1.308^{* * *} \\
(0.000)\end{array}$ \\
\hline $\log$ (number of phones per 1,000 population) & $\begin{array}{l}-0.445 * * * \\
(0.000)\end{array}$ & $\begin{array}{c}-0.474 * * * \\
(0.000)\end{array}$ & $\begin{array}{c}-0.393^{* * *} \\
(0.003)\end{array}$ & $\begin{array}{c}-0.449 * * * \\
(0.006)\end{array}$ \\
\hline Rule of law & $\begin{array}{l}-0.234 * * * \\
(0.010)\end{array}$ & $\begin{array}{c}-0.227 * * \\
(0.015)\end{array}$ & $\begin{array}{c}-0.271 * * * \\
(0.007)\end{array}$ & $\begin{array}{c}-0.252 * * \\
(0.025)\end{array}$ \\
\hline British heritage $(A N G L O)$ & $\begin{array}{c}0.118 \\
(0.575)\end{array}$ & $\begin{array}{c}0.176 \\
(0.414)\end{array}$ & $\begin{array}{c}0.369 \\
(0.113)\end{array}$ & $\begin{array}{c}0.436 \\
(0.102)\end{array}$ \\
\hline Non-Anglo European & $\begin{array}{c}0.268^{*} \\
(0.091)\end{array}$ & $\begin{array}{l}0.345^{* *} \\
(0.034)\end{array}$ & $\begin{array}{l}0.503^{* * * *} \\
(0.005)\end{array}$ & $\begin{array}{l}0.561^{* * * *} \\
(0.006)\end{array}$ \\
\hline Latin America & $\begin{array}{l}0.851 * * * \\
(0.000)\end{array}$ & $\begin{array}{l}0.858^{* * * *} \\
(0.000)\end{array}$ & $\begin{array}{l}0.925^{* * * *} \\
(0.000)\end{array}$ & $\begin{array}{l}0.767 * * * \\
(0.001)\end{array}$ \\
\hline Log-likelihood & -724.39 & -691.70 & -601.41 & -517.00 \\
\hline Observations & 2416 & 2268 & 1823 & 1523 \\
\hline
\end{tabular}

(Dependent variable equals one if the subsidiary is wholly owned and equals zero otherwise)

$P$-values are in parenthesis, and $* * * * *$, and $*$ denote significance at $0.01,0.05$, and 0.10 levels, respectively. Except for variables noted below, all others are defined in table 3 .

a Dummy variable is equal to zero if the subsidiary reports directly to the U.S. parent.

${ }^{\mathrm{b}}$ Dummy variable is equal to one if TNE's stocks are publicly traded.

c Dummy variable is equal to one if the subsidiary is in resource-based manufacturing sector.

d Interaction of PETMIN (dummy variable $=1$ if subsidiary is in mining or petroleum) and a measure of backward vertical integration BVERT measured by the share of TNE's imports supplied by subsidiary.

' Interaction of manufacturing resource-based dummy variable (RESBASED) and the measure of backward vertical integration (BVERT).

${ }^{\mathrm{f}}$ This dummy variable is part of wholesale and therefore was not included in regressions (3) and (4) 
we control for a specific manufacturing effect, which itself is negative.

Country indicators generally produce the predicted pattern in the probit model: according to table 4 , the probability of whole ownership rises with educational attainment, the share of nonagricultural employment, the sociocultural affinity of the host country with the United States, and the absence of market interventions and expropriation risk in the host country. ${ }^{41}$ All of these factors reduce the comparative advantage of local entrepreneurs and diminish the need for recruiting them as partners. The opposite is the case for PATENT, which measures the technological capability of local producers. The results also show that joint ventures are more likely when the country is better endowed with physical and institutional infrastructure (proxied by the number of telephones and rule of law), which make FDI projects more productive and increase the host country pressure for rent sharing. ${ }^{42}$ Openness proved insignificant and was omitted from the reported regressions, but it seems to be overshadowed by PATENT, which is correlated with it. When the latter is omitted, openness always has a positive and significant coefficient. Measures of market size, GDP growth, and investment rate reach little significance and are not reported. However, they turn significant and are all negatively related to EQUITY when the telephone availability indicator is omitted from the regression. ${ }^{43}$ The restrictiveness of equity policy (RESTRICT) has a definite, negative effect on EQUITY. However, it is by no means the dominant force.

We now discuss the estimation results of the truncated model. Using the same variables as the basic probit model for the sample of joint ventures yields coefficients that generally have the same signs as in the probit model, however, many of the variables lose significance. This is not surprising because the variables that influence the choice between whole versus partial ownership may not be very relevant in the determination of $\beta$ in joint ventures. In addition, truncated regressions are generally more volatile than probit or tobit regressions. The smaller size of the sample may also contribute to the instability of the results. To present regressions that have reasonably significant coefficients, we eliminate the variables that do not perform well. Table 5 reports the end result with some of its variations.

\footnotetext{
${ }^{41}$ We also used the measure of ethnolinguistic diversity popularized by Easterly and Levine (1997). We expected a negative coefficient because operating in a culturally diversified country may require more detailed local knowledge in relations with customers, employees, officials, and so forth. The result had the correct sign, but limited significance.

${ }^{42}$ Other indicators of host country institutions, such as bureaucratic quality, corruption, and contract repudiation, were not significant. Interestingly, the corruption index, whose effect is theoretically ambiguous, proves insignificant even when the rule-of-law index is omitted from the regression.

${ }^{43}$ Gomes-Casseres (1990) finds that GDP growth rate has a negative impact on the probability of full ownership only in restrictive countries. Our experiments with the interaction of growth rate, and RESTRICT did not yield any significant results.
}

In the truncated model, TNE experience variables and PUBTRADE do not show any significance. This is, by and large, the case for REGIONAL as well. (See columns 1 through 3 of table 5.) However, the sales-asset ratio is consistently significant, confirming its importance as a measure of TNE's intangible assets. DIVERSE also remains significant, indicating that diversified TNEs have a greater need for local partners. Among industry characteristics, the relevant variables for joint ventures are resource intensity and backward integration, especially in petroleum, coal, and mining. Concerning country variables, equity restrictions, schooling, European dummy, technological capabilities of local firms, and institutional and physical infrastructure prove consequential for joint ventures just as they affect the probability of whole ownership. ${ }^{44}$ Note that all of the country characteristics that lose their significance compared with the probit model (share of nonagricultural labor, expropriation risk, BLACK, and ANGLO and LATIN dummies) are those that affect the parameter $\rho$. This outcome conforms well to our theoretical observation that $\rho$ is relevant in the choice of whole versus joint ownership, but it plays no role in the division of shares between joint venture partners.

\section{Concluding Remarks}

This paper has examined the extent to which equity restrictions and country conditions affect ownership decisions of TNEs. The key contribution is the unified interpretation provided for the determinants of equity positions in FDI projects. We also develop innovative measures for firm, industry, and country characteristics that influence equity composition. It is shown that ownership structure depends on the relative productivities of the TNEs' assets, the local entrepreneurs' capabilities, and the host country's physical infrastructure and institutional setting.

From a policy perspective, our results suggest that simply removing equity restrictions may have little effect in improving the country's environment for foreign investment. If there are significant restrictions on domestic markets and if the host population is uneducated and unfamiliar with modern industry and services, TNEs are likely to find investment costly. If they do choose to invest, they will mitigate the difficulties by forming joint ventures. A more effective means of attracting foreign investment in such situations is to improve the country's physical and institutional infrastructure. Interestingly, as the business environment becomes more attractive to foreign investors, the host government's desire to retain larger surpluses in the country strengthens, and the pressure for local equity participation may increase. This is not necessarily bad for foreign investment because it provides an incentive for countries to improve their infrastructure, thereby creating conditions that enhance productivity and attract more FDI.

\footnotetext{
${ }^{44}$ The insignificance of telephone availability in column 1 of table 5 is due to its high correlation with the rule of law. See column 2.
} 
Table 5.-Truncated Model Determinants of Foreign Equity Share in Joint Ventures

\begin{tabular}{|c|c|c|c|c|}
\hline Variables & (1) & (2) & (3) & (4) \\
\hline Intercept & $\begin{array}{l}0.727 * * * \\
(0.000)\end{array}$ & $\begin{array}{l}0.811^{* * *} * \\
(0.000)\end{array}$ & $\begin{array}{l}0.600 * * * \\
(0.000)\end{array}$ & $\begin{array}{l}0.629 * * * \\
(0.000)\end{array}$ \\
\hline \multicolumn{5}{|l|}{ Firm Characteristics } \\
\hline Log (TNE sales/assets) & $\begin{array}{l}0.071 * * \\
(0.046)\end{array}$ & $\begin{array}{l}0.074 * * \\
(0.043)\end{array}$ & $\begin{array}{l}0.075 * * \\
(0.036)\end{array}$ & $\begin{array}{c}0.069 * \\
(0.051)\end{array}$ \\
\hline Production diversity of TNE & $\begin{array}{c}-0.012 * * * \\
(0.007)\end{array}$ & $\begin{array}{c}-0.012 * * * \\
(0.007)\end{array}$ & $\begin{array}{c}-0.012 * * * \\
(0.006)\end{array}$ & $\begin{array}{c}-0.013 * * * \\
(0.005)\end{array}$ \\
\hline Organizational structure dummy & $\begin{array}{c}0.085 \\
(0.147)\end{array}$ & $\begin{array}{c}0.082 \\
(0.167)\end{array}$ & $\begin{array}{c}0.085 \\
(0.151)\end{array}$ & \\
\hline \multicolumn{5}{|l|}{ Industry Characteristics } \\
\hline RESBASED & $\begin{array}{c}-0.052 \\
(0.115)\end{array}$ & $\begin{array}{r}-0.043 \\
(0.191)\end{array}$ & $\begin{array}{r}-0.054 \\
(0.102)\end{array}$ & $\begin{array}{c}-0.056^{*} \\
(0.091)\end{array}$ \\
\hline$B V E R T$ & $\begin{array}{c}-0.155^{* *} \\
(0.028)\end{array}$ & $\begin{array}{c}-0.155^{* *} * \\
(0.030)\end{array}$ & $\begin{array}{c}-0.152 * * \\
(0.032)\end{array}$ & $\begin{array}{c}-0.16^{* *} * \\
(0.028)\end{array}$ \\
\hline PETMIN * BVERT & $\begin{array}{c}-0.241 * \\
(0.081)\end{array}$ & $\begin{array}{c}-0.265^{*} \\
(0.057)\end{array}$ & $\begin{array}{c}-0.236^{*} \\
(0.090)\end{array}$ & $\begin{array}{c}-0.236^{*} \\
(0.090)\end{array}$ \\
\hline \multicolumn{5}{|l|}{ Industry Dummies } \\
\hline Electronic components & $\begin{array}{c}0.131 * \\
(0.061)\end{array}$ & $\begin{array}{c}0.130 * \\
(0.068)\end{array}$ & $\begin{array}{c}0.131 * \\
(0.063)\end{array}$ & $\begin{array}{c}0.126 * \\
(0.074)\end{array}$ \\
\hline \multicolumn{5}{|l|}{ Country Characteristics } \\
\hline Equity restrictions & $\begin{array}{c}-0.004 * * \\
(0.020)\end{array}$ & $\begin{array}{c}-0.004 * * \\
(0.026)\end{array}$ & $\begin{array}{c}-0.003 * * \\
(0.049)\end{array}$ & $\begin{array}{c}-0.003^{* *} * \\
(0.028)\end{array}$ \\
\hline Share of patents granted to local firms & $\begin{array}{c}-0.168 * * * \\
(0.000)\end{array}$ & $\begin{array}{c}-0.175^{* * * *} \\
(0.001)\end{array}$ & $\begin{array}{c}-0.167 * * * \\
(0.000)\end{array}$ & 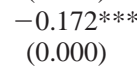 \\
\hline Log (average years of schooling) & $\begin{array}{l}0.272 * * * \\
(0.004)\end{array}$ & $\begin{array}{l}0.180 * * * \\
(0.006)\end{array}$ & $\begin{array}{l}0.244 * * * \\
(0.000)\end{array}$ & $\begin{array}{l}0.235^{* * * *} \\
(0.012)\end{array}$ \\
\hline Log (number of phones per 1,000 population) & $\begin{array}{r}-0.034 \\
(0.213)\end{array}$ & $\begin{array}{c}-0.057^{* * *} \\
(0.028)\end{array}$ & & \\
\hline Rule of law & $\begin{array}{c}-0.054 * * \\
(0.017)\end{array}$ & & $\begin{array}{c}-0.064 * * * \\
(0.003)\end{array}$ & $\begin{array}{c}-0.064 * * * \\
(0.003)\end{array}$ \\
\hline Non-Anglo European & $\begin{array}{l}0.196 * * * \\
(0.000)\end{array}$ & $\begin{array}{l}0.180 \text { *** } \\
(0.000)\end{array}$ & $\begin{array}{l}0.185 * * * \\
(0.000)\end{array}$ & $\begin{array}{l}0.183 \text { *** } \\
(0.000)\end{array}$ \\
\hline Log-likelihood & 108.06 & 105.13 & 107.27 & 106.20 \\
\hline Observations & 331 & 331 & 331 & 331 \\
\hline
\end{tabular}

$P$-values are in parenthesis, and $* * *, * *$, and $*$ denote significance at $0.01,0.05$, and 0.10 levels, respectively. For a description of the variables, see the notes for tables 3 and 4 .

An important question is whether there are less costly ways for host governments to achieve their objectives, that is, to retain more of the FDI surplus without imposing restrictions. ${ }^{45}$ According to our model, one solution to this problem is improved taxation. If the government can ensure that a larger share of the surplus is retained in the country by a system of less distortionary taxes and payments for the use of the country's assets, it will have less incentive to restrict the foreign equity share. However, this seems to be the heart of the problem in most less-developed countries, where governments do not have the administrative capability to monitor effectively and organize the tax system efficiently. Indeed, it may help explain why host governments in institutionally weak countries are so much more disposed to using crude mechanisms for rent redistribution (Esfahani, 2000). The other side of the coin is that, in such environments, improving the government's administrative capabilities may produce a double dividend: first, a more effective tax system can induce positive reform in FDI policies, and,

\footnotetext{
${ }^{45}$ It is interesting to note that, in order to attract FDI, a number of countries not only removed restrictions but also provided incentives such as tax breaks to TNEs. Consequently, many governments experienced a decrease in revenues without receiving a strong response from foreign investors.
}

second, a better administration and a more open FDI policy can contribute to institutional reliability. Both effects can make the country more attractive to foreign investors and increase the payoff from the resulting investments.

\section{REFERENCES}

Anderson, Erin, and Hubert Gatignon, "The Multinational Corporation's Degree of Control over Foreign Subsidiaries: An Empirical Test of a Transaction Cost Explanation," Journal of Law, Economics, and Organization 4:2 (1988), 305-336.

Asiedu, Elizabeth, and Hadi Salehi Esfahani, "The Determinants of Restrictive FDI Policies: A Cross-Country Analysis of Restrictions Experienced by US Firms," University of Illinois, mimeograph (2000).

Barro, Robert J., and Jong-Wha Lee, "International Comparisons of Educational Attainment," Journal of Monetary Economics 32:3 (1993), 363-394.

Beamish, Paul W., "Joint Ventures in LDCs: Partner Selection and Performance," Management International Review 34:2 (1994), 61-74.

Caves, Richard E., Multinational Enterprise and Economics Analysis (New York: University Press, 1982).

Campos, J., Edgardo, Donald Lien, and Sanjay Pradhan, "The Impact of Corruption on Investment: Predictability Matters," World Development 27:6 (1999), 1059-1067.

Choi, Yongjae, and Hadi Salehi Esfahani, "Direct Foreign Investment and Expropriation Incentives: A Mitigating Role for Match-Specific Capital," Quarterly Review of Economics and Finance 38:1 (1998), 47-60. 
Connolly, Michelle, "The Dual Nature of Trade: Measuring its impact on Imitation and Growth," Duke University Department of Economics working paper no. 97-34 (1998).

Contractor, Farok, "Ownership patterns of U.S. Joint Ventures Abroad and the Liberalization of Foreign Regulations in the 1980s: Evidence from the Benchmark Surveys," Journal of International Business Studies 21:1 (1990), 55-73.

, Government Policies and Foreign Direct Investment, United Nations Center on Transnational Corporations (UNCTC) Current Studies, Series A no. 17, (New York: United Nations Publication, 1991).

Cragg, John G., "Some Statistical Models for Limited Dependent Variables with Application to the Demand for Durable Goods," Econometrica 39:5 (1971), 829-844.

Davidson, William H., Global Strategic Management (New York: John Wiley and Sons, 1982).

Davidson, William H., and Donald G. McFetridge, "International Technology Transactions and the Theory of the Firm," The Journal of Industrial Economics 32:3 (1984), 253-264.

_ , "Key Characteristics in the Choice of International Technology Transfer Mode," Journal of International Business Studies 16:2 (1985), 5-21.

Dasgupta, Sudipto, and Kunal Sengupta, "Optimal Regulation of MNEs and Government Revenues," Journal of Public Economics 58:2 (1995), 215-234.

Doyle, Chris, and Sweder van Wijnbergen, "Taxation of Foreign Multinationals: A Sequential Bargaining Approach to Tax Holidays." International Tax and Public Finance 1:3 (1994), 211-225.

Easterly, William, and Ross Levine, "Africa's Growth Tragedy: Policies and Ethnic Divisions," Quarterly Journal of Economics 112:4 (1997), 1203-1250.

Erramilli, Krishna M., "The Experience Factor in Foreign Market Entry Behavior of Service," Journal of International Business Studies 22:3 (1991), 479-501.

, "Nationality and Subsidiary Ownership Patterns in Multinational Corporations," Journal of International Business 27:1 (1996), 225-248.

Esfahani, Hadi Salehi, "Institutions and Government Controls," Journal of Development Economics 63:2 (2000), 197-229.

Eswaran, Mukesh, and Ashok Kotwal, "A Theory of Contractual Structure in Agriculture," American Economic Review 75:3 (1985), 353-367.

Falvey, Rodney E., and Harold O. Fried, "National Ownership Requirements and Transfer Pricing," Journal of Development Economics 24:2 (1986), 249-254.

Gomes-Casseres, Benjamin, "Ownership Structures of Foreign Subsidiaries; Theory and Evidence," Journal of Economic Behavior and Organization 11:1 (1989), 1-25.

, "Firm Ownership Preferences and Host Government restrictions: An Integrated Approach," Journal of International Business 21:1 (1990), 1-22.

Grossman, Sanford J., and Oliver D. Hart, "The Costs and Benefits of Ownership: A Theory of Vertical and Lateral Integration," Journal of Political Economy 94:4 (1986), 691-719.

Henisz, Witold J., "The Institutional Environment for Multinational Investment," Journal of Law, Economics \& Organization, 16:2 (2000), 334-364.

Hennart, Jean-Francois, "A Transactions Costs Theory of Equity Joint Ventures," Strategic Management Journal 9 (1988), 361-374. , "The Transaction Cost Theory of the Multinational Enterprise" (pp. 81-116), in Christos N. Pitelis and Roger Sugden (Eds.), The Nature of the Transnational Firm (London: Routledge, 1990). , "The Transactions Costs Theory of Joint Ventures: An Empirical Study of Japanese Subsidiaries in the United States," Journal of Management Science 37:4 (1991), 483-497.

Heston, Alan, and Robert Summers, "International Price and Quantity Comparisons: Potentials and Pitfalls," American Economic Review 86:2 (1996), 20-24.

Johanson, Jan, and Jan-Erik Vahlne, "The Internationalization Process of the Firm: A Model of Knowledge Development and Increasing Foreign Commitments," Journal of International Business 8:1 (1977), 23-32.

Johnson, Bryan T., and Thomas Sheehy, Index of Economic Freedom (Washington, DC: The Heritage Foundation, 1996).
Knack, Stephen, and Philip Keefer, "Institutions and Economic Performance: Cross-Country Tests Using Alternative Institutional Measures," Economics and Politics 7:3 (1995), 207-227.

Kogut, Bruce, and Harbir Singh, "The Effect of National Culture on the Choice of Entry Mode," Journal of International Business 19:3 (1988), 411-432.

Kumar, Nagesh, "Intellectual Property Protection, Market Orientation and Location of Overseas R\&D Activities by Multinational Enterprises," World Development 24:4 (1996), 673-688.

LaPorta, Rafael, Florencio Lopez-de-Silanes, Andrei Shleifer, and Robert W. Vishny, "The Quality of Government," Journal of Law, Economics and Organization 15:1 (1999), 222-279.

Lee, Jeong-Yeon, and Edwin Mansfield, "Intellectual Property Protection and U.S. Foreign Investment," this REVIEW 78:2 (1996), 181-186.

Lin, Tsai-Fein, and Peter Schmidt, "A Test of the Tobit Specification Against Suggested by Cragg," this REVIEW 66:1 (1984), 174-177.

Markusen, James R., "The Boundaries of Multinational Enterprises and the Theory of International Trade," Journal of Economic Perspectives 9:2 (1995), 169-189.

National Register, Directory of Corporate Affiliations (Skokie I1: National Register Publishing Company, 1997).

Pan, Yipang, "Influences on Foreign Equity Ownership Level in Joint Ventures in China," Journal of International Business 27:1 (1996), $1-26$.

Schnitzer, Monika, "Expropriation and Control Rights: A Dynamic Model of Foreign Direct Investment," International Journal of Industrial Organization 17:8 (1999), 113-1137.

Stopford, John M., and Louis T. Wells, Managing the Multinational Enterprise: Organization of the Firm and Ownership of the Subsidiaries (New York: Basic Books, 1972).

Stoughton, Neal, and Eli Talmor, "A Mechanism Design Approach to Transfer Pricing by the Multinational Firm," European Economic Review 38:1 (1994), 143-170.

Svejnar, Jan, and Stephen C. Smith, "The Economics of Joint Ventures in Less Developed Countries," Quarterly Journal of Economics 99:1 (1984), 149-167.

United Nations Center on Transnational Corporations (UNCTC), World Investment Report (New York: United Nations Publication, various issues).

United Nations Center for Trade and Development (UNCTD), Liberalizing International Transactions in Services: A Handbook (New York: United Nations Publication, 1994).

, Foreign Direct Investment in Africa (New York: United Nations Publication, 1995).

U.S. Department of Commerce, Benchmark Survey of U.S. Direct Investment Abroad (Washington, DC: U.S. Department of Commerce, Bureau of Economic Analysis, various issues).

, Survey of Current Business (Washington, DC: U.S. Department of Commerce, Bureau of Economic Analysis, 1995).

Vernon, Raymond, Sovereignty at Bay: The Multinational Spread of U.S. Enterprises (New York: Basic Books, 1971).

World Bank, World Development Finance, CD-ROM (2000).

\section{APPENDIX A}

Claim 1: Taking into account the possibility of random effects in the ownership decision, the probability that the TNE prefers whole ownership rises with $\lambda$ and declines with $\nu$ and $\rho$, whereas $\eta$ plays an ambiguous role.

Proof: $\quad$ Let $H$ denote the right-hand side of equation (11). Note that $\gamma_{t}$ (and therefore $\beta_{t}$ ) maximizes $H$. Therefore, using the envelope theorem, it is easy to see that $H$ increases as $\lambda$ declines or $\rho$ rises. For $\eta$ we have,

$$
\frac{\partial \log H}{\partial \eta}=\frac{-v / \eta^{2}}{1+v / \eta}-\frac{\lambda}{\eta^{2}} \log \gamma_{t}-\frac{v}{\eta^{2}} \log \left[\left(1-\gamma_{t}\right) \rho\right] .
$$

Substituting from $\log H=0$ for the last two terms on the right-hand side of equation (A1) and using equation (10), we get 


$$
\begin{aligned}
\frac{\partial \log H}{\partial \eta}=\frac{1}{\eta} & {\left[-\frac{v / \eta}{1+\nu / \eta}+\log \left(1+\frac{\nu}{\eta}\right)\right.} \\
& \left.+\log \left(\frac{\eta+\lambda}{\eta+\lambda+\nu}\right)\right] .
\end{aligned}
$$

The sum of the first two terms in the brackets is positive. If $\lambda$ is sufficiently large relative to $v$ and $\eta$, then the last term will be close to zero and $\partial \log H / \partial \eta>0$. However, if $\lambda$ is relatively small, then the third term will almost cancel the second term and $\partial \log H / \partial \eta$ can be zero or negative.

For $\nu$, using $\log H=0$ and equation (10), we have

$$
\begin{aligned}
\frac{\partial \log H}{\partial v} & =\frac{v}{\eta+v}+\frac{v}{\eta} \log \left(\frac{\rho v}{\eta+\lambda+v}\right) \\
& =\frac{v}{\eta+v}-\log \left(\frac{\eta+v}{\eta}\right)+\frac{\eta+\lambda}{\eta} \log \left(\frac{\eta+\lambda+v}{\eta+\lambda}\right),
\end{aligned}
$$

where, on the right-hand side, we have substituted from $\log H=0$. When $v$ is close to zero, $\partial \log H / \partial v>0$. This is also true for higher values of $v$ because $\partial \log H / \partial v$ rises with $v$ :

$$
\frac{\partial^{2} \log H}{\partial^{2} v}=\frac{1}{\eta+v}\left(\frac{\eta+v}{\eta+\lambda+v} \frac{\eta+\lambda}{\eta}-\frac{v}{\eta+v}\right)>0 .
$$

Claim 2: The government's preferred $\gamma$ (or $\beta$ ) is always lower than that of the TNE. Furthermore, $\gamma_{g}$ (and therefore $\beta_{g}$ ) rises with $\lambda$, but declines with $\eta$ and $\nu$.

Proof: Equation (13) has two solutions, one of which is between $\lambda /(\eta+\lambda+\nu)$ and $\lambda /(\lambda+\nu)$ and yields a maximum. The first part of the proof follows from the fact that $\gamma_{g}<\lambda /(\lambda+\nu)<\frac{\eta+\lambda}{\eta+\lambda+v}$ $=\gamma_{t}$. The second part follows from the first and second derivatives of equation (13).

Claim 3: The probability that the government prefers whole ownership rises with $\lambda$ and $\tau$, and declines with $\eta$ and $\rho$, whereas $\nu$ plays an ambiguous role.

Proof: Let $K$ denote the right-hand side of equation (14). Clearly, $\partial$ $\log K / \partial \rho>0$ and $\partial \log K / \partial \tau<0$. For $\eta$ we have,

$$
\begin{aligned}
\frac{\partial \log K}{\partial \eta}= & \left(\frac{1}{\eta+\lambda+\nu} \frac{1}{\eta+\lambda} \frac{\nu}{\eta}\right) \frac{x}{1+x} \\
& -\frac{\lambda}{\eta^{2}} \log \gamma_{g}-\frac{\nu}{\eta^{2}} \log \left[\left(1-\gamma_{g}\right) \rho\right],
\end{aligned}
$$

where $x=\left(1-\gamma_{g}\right)\left(\frac{1-\tau}{\tau}\right)\left(\frac{\eta+\lambda}{\eta+\lambda+v}\right)$. When $\log K$ is close to zero, we can write

$$
\frac{\partial \log K}{\partial \eta}=\left(\frac{1}{\eta+\lambda+v} \frac{1}{\eta+\lambda} \frac{\nu}{\eta}\right) \frac{x}{1+x}+\frac{1}{\eta} \log (1+x)>0
$$

For $v$ we have,

$$
\frac{\partial \log K}{\partial \nu}=-\left(\frac{1}{\eta+\lambda+v}\right) \frac{x}{1+x}+\frac{1}{\eta} \log \left[\left(1-\gamma_{g}\right) \rho\right],
$$

When $\log K$ is close to zero, equation (A7) yields

$$
\frac{\partial \log K}{\partial \nu}=-\left(\frac{1}{\eta+\lambda+v}\right) \frac{x}{1+x}-\frac{1}{\nu} \log (1+x)-\frac{\lambda}{\eta \nu} \log \gamma_{g}
$$

Note that, if $\tau=1, x=0$ and $\partial \log K / \partial v>0$, while if $\tau$ is close to 0 , $x$ would be very large and, thus, $\partial \log K / \partial v<0$.
For $\lambda$ we have,

$$
\frac{\partial \log K}{\partial \lambda}=-\left(\frac{v}{\eta+\lambda+v} \frac{1}{\eta+\lambda}\right) \frac{x}{1+x}+\frac{1}{\eta} \log \gamma_{g} .
$$

In this case, if $\tau$ is close to $1, x$ is close to 0 and $\partial \log K / \partial \lambda<0$. As $\tau$ declines, $x /(1+x)$ grows and $\beta_{g}^{*}$ declines. As a result, $\partial \log K / \partial \lambda$ always remains negative.

\section{APPENDIX B}

\section{Data Sources and Description}

Data for the dependent variable, the share of equity owned by a U.S. parent company in its foreign subsidiary, and other firm characteristics were obtained from the 1997 edition of the Directory of Corporate Affiliations. The data cover U.S. TNEs operating in 1996 with a revenue of at least $\$ 10$ million or a workforce in excess of 300 persons. Industry data were obtained from the U.S. Direct Investment Abroad: 1994 Benchmark Survey Data published by the Department of Commerce. The survey, which is conducted every five years, provides detailed financial data on the operations of non-bank U.S. parent companies and their non-bank foreign subsidiaries. The 1994 survey covered all foreign affiliates of U.S. direct investors (foreign companies owned $10 \%$ or more by a U.S. person) that had assets, sales, or net income of at least $\$ 3$ million. This comprised 2,658 non-bank U.S. parents and 21,300 nonbank affiliates.

Data for the number of U.S. firms that were asked to limit equity in their subsidiaries were acquired from the U.S. Direct Investment Abroad: 1982 Benchmark Survey Data. The data are based on the response to a question asking whether any level of government of the country in which affiliate is located requires by law, regulation, or administrative practice that the affiliate limit the proportion of equity that the parent may hold in the affiliate as a condition for it to operate in the country, to expand its operations, or to receive investment incentives during the 1982 fiscal year. The survey covered 18,339 affiliates.

Data on the host country's resources and infrastructure such as GDP, investment, growth rate, telephone availability and educational attainment were obtained from the dataset used by Barro and Lee (1993), Easterly and Levine (1997), and Heston and Summers (1996). Data on the host country's institutions such as the degree to which contracts are enforced, bureaucratic quality, rule of law, expropriation risk, and corruption were

\begin{tabular}{|c|c|c|c|c|}
\hline $\begin{array}{l}\text { British Heritage } \\
\quad \text { (Anglo) }\end{array}$ & $\begin{array}{l}\text { Non-Anglo } \\
\text { Europe }\end{array}$ & Asia & $\begin{array}{c}\text { Latin } \\
\text { America }\end{array}$ & Other \\
\hline $\begin{array}{l}\text { Australia } \\
\text { Canada } \\
\text { Ireland } \\
\text { New Zealand } \\
\text { United Kingdom }\end{array}$ & $\begin{array}{l}\text { Austria } \\
\text { Belgium } \\
\text { Denmark } \\
\text { Finland } \\
\text { France } \\
\text { Germany } \\
\text { Greece } \\
\text { Italy } \\
\text { Netherlands } \\
\text { Norway } \\
\text { Portugal } \\
\text { Spain } \\
\text { Sweden } \\
\text { Switzerland } \\
\text { Turkey }\end{array}$ & $\begin{array}{l}\text { Hong Kong } \\
\text { India } \\
\text { Japan } \\
\text { Korea } \\
\text { Malaysia } \\
\text { Philippines } \\
\text { Singapore } \\
\text { Thailand }\end{array}$ & $\begin{array}{l}\text { Argentina } \\
\text { Brazil } \\
\text { Chile } \\
\text { Colombia } \\
\text { Ecuador } \\
\text { Mexico } \\
\text { Panama } \\
\text { Peru } \\
\text { Venezuela }\end{array}$ & $\begin{array}{l}\text { Egypt } \\
\text { Jamaica } \\
\text { Nigeria } \\
\text { South Africa } \\
\text { Trinidad }\end{array}$ \\
\hline
\end{tabular}
obtained from the International Country Risk Guide (ICRG) data set. These are survey-based indicators and range from 1 to 6 , except for expropriation risk and contract indices that range from 1 to 10. Data on the share of black market in the economy were obtained from Johnson and Sheehy (1996). This variable ranges from 1 (less than 10\%) to 5 (greater than $30 \%$ ). Data on patents were made available to us by Michelle P. Connoly of Duke University, for which we are thankful. Country data were measured as averages for the prior ten to fifteen years, depending on data availability.

Table B1.-Countries Grouped by Sociocultural Distance 